\title{
MODELOS DIPLOMÁTICOS DE CARTAS DE VENTA SEGÚN ALGUNOS EJEMPLOS EXTREMEÑOS DEL SIGLO XIV
}

\author{
Tomás Puñal Fernández
}

\section{Introducción}

La investigación histórica cuenta con las fuentes documentales como el principal método de trabajo para reconstruir los aspectos políticos, sociales o económicos, entre otros, del pasado más remoto o más inmediato. En este sentido los documentos contribuyen a aportar determinados datos, que debidamente analizados, cotejados y contrastados, son la base de la teoría histórica. Debido a ello, la diplomática, como ciencia historiográfica con unos objetivos y una metodología propias, aporta el conocimiento de los documentos, no sólo desde un punto de vista puramente técnico, sino al mismo tiempo de contenido histórico y a través de su estudio y análisis contribuye, por lo tanto, con su aportación a enriquecer el conocimiento histórico.

En el presente trabajo analizaremos desde esta perspectiva un conjunto de documentos medievales pertenecientes al patrimonio documental extremeño y que, por tanto, serán una aportación más a la historia de un territorio, el de la baja Extremadura. Según la ley del patrimonio histórico y cultural de Extremadura del año 1999, el mismo consta de cualesquier fondos y colecciones documentales existentes en los archivos de la región o fuera de ella procedentes de instituciones y personas públicas o privadas ${ }^{2}$. Esta definición abarca, pues, a un importante volumen de documentos, que desde la Edad Media, han

1. Universidad de Extremadura.

2. Título VI sobre el patrimonio documental y bibliográfico de la ley del patrimonio histórico y cultural de Extremadura, 2 /99 de 29 de marzo. Publicada en el DOE. no 59 de 22 de mayo de 1999. 
contribuido y contribuyen a conocer con más precisión la historia de esta región hasta nuestros días.

Uno de estos fondos es el que se conserva en el Archivo Histórico Nacional de Madrid en su sección de clero. Se trata de un conjunto de cinco pergaminos fechados entre 1355 y 1400 procedentes, según consta en el propio catálogo de esta sección, del convento de franciscanas de Santa Clara de Zafra ${ }^{3}$. Se trata de algunos de los documentos confiscados tras las desamortizaciones producidas en la España liberal del siglo $\mathrm{XIX}^{4}$ que afectaron básicamente a las instituciones religiosas, despojando a conventos y monasterios de distintas órdenes de un caudal documental importante, parte del cual, después de diversas vicisitudes, fue a parar al Archivo Histórico Nacional creado por Real Decreto de 28 de marzo de 1866 para guardar aquellos fondos históricos procedentes de otros archivos centrales a donde habían ido a parar tras el proceso desamortizador.

Desconocemos si en dicho archivo se conserva toda la documentación que en su día fuera confiscada a las clarisas de Zafra o sólo una parte de la misma. Lo que sí es cierto es que se trata de unos pocos documentos referentes al mismo tema y que según sabemos, por información del propio convento, en su archivo existen aún más documentos que las monjas pudieron conservar.

Los pergaminos que analizamos se refieren a cinco cartas de venta de distintas heredades situadas en el territorio conocido en los documentos medievales como Zafinos, actual Zahínos, en el término municipal de Jerez de los Caballeros. Todas estas tierras compuestas por sembradura y pastos constituían una enorme dehesa que en los documentos que analizamos aparece perfectamente delimitada a través de una serie de topónimos, no haciéndose mención, en ningún momento, a la existencia de ningún núcleo de población vertebrador del territorio, a excepción de la propia villa de Jerez de los Caballeros.

Las ventas realizadas tanto por particulares como por los miembros de una misma familia desde 1355 hasta 1400 estaban encaminadas a formar una especie de pequeño latifundio a favor de Gonzalo Domínguez y su descendencia.

3. "Archivo Histórico Nacional, Sección de Clero. Inventario de pergaminos", Madrid (19491968), p. 41. El título figura como Franciscanas menores observantes de Santa Clara dentro del apartado de Zafra.

4. Las desamortizaciones fueron la consecuencia final de un proceso iniciado tras la Guerra de la Independencia a comienzos del siglo XIX y concretado en la labor legislativa de las Cortes de Cádiz de 1810 y en la Constitución de 1812 conducente a acabar con los resquicios de estructuras feudales que aún quedaban en España, limitando, entre otros, el poder de la Iglesia que había sido la principal institución feudal en cuanto poseedora de bienes inmuebles y raíces. Este proceso se completó a lo largo del siglo XIX bajo el reinado de Isabel II. Las desamortizaciones más importantes en cuanto a documentos procedentes de instituciones eclesiásticas fueron las del ministro Mendizábal en 1835 y sobre todo las de Pascual Madoz. Sobre bibliografía del tema ver T. MARTíN, La desamortización, Madrid, 1973. Más específico sobre la región extremeña, J.P. MERINO NAVARRO, Notas sobre la desamortización en Extremadura, Madrid, 1976. 
De esta manera el primogénito, que suponemos a Gonzalo Domínguez, hijo de un tal Domingo Zurame, fue adquiriendo, primero de su hermana y luego de otros vecinos, algunas propiedades, todas ellas en Zahínos. Su hijo y sucesor Álvaro González Chico lejos de disipar esta herencia paterna fue acrecentando el patrimonio, adquiriendo la parte que, por derecho de herencia, pertenecía a alguno de sus hermanos.

El proceso demuestra varias cosas. Primero como hacia finales del siglo XIV, en Extremadura, se mantiene una estructura social en la que el cabeza de una familia, posiblemente ya de tipo nuclear, reparte sus bienes y propiedades a través de la herencia entre sus hijos ${ }^{5}$. Se trata de una norma recogida en el derecho medieval desde Las Partidas de Alfonso X, el sabio, en la segunda mitad del siglo XIII. Dicho código dedica nada menos que la sexta partida a lo largo de sus diecinueve títulos a legislar sobre el tema ${ }^{6}$.

Sobre la parte de la herencia correspondiente por derecho natural a los hijos $^{7}$, Ilamada legítima, se habla en diversas ocasiones ${ }^{8}$, poniendo de manifiesto el derecho irrenunciable de los herederos a recibir de los bienes paternos esta parte, libremente y sin ninguna condición ${ }^{9}$. Esto significa que todos los herederos legítimos debían beneficiarse de la herencia que debía ser repartida, sino a partes iguales, por lo menos en proporción al número de hijos. En la documentación que analizamos se hace referencia varias veces al derecho de propiedad por herencia:

"Otorgamos y conocemos que vendemos a vos...... que estais presente..... toda la parte y gobierno y derecho que nos habemos y nos pertenece de una heredad...." ${ }^{10}$.

En otro orden de cosas todo apunta a que lo largo de la baja Edad Media se produjo una evolución del derecho de propiedad hacia la concentración en

5. Así se pone de manifiesto en la sociedad cacereña del siglo XIII donde la estructura familiar es la nuclear; J. CLEMENTE RAMOS, La sociedad en el fuero de Cáceres (siglo XIII), Cáceres, 1990, p. 45 y ss.

6. Seguimos la edición de las Siete Partidas realizada en Salamanca en 1555 por Andrea de Portonariis y glosadas por el licenciado Gregorio López, publicadas por la editorial del Boletín Oficial del Estado. También se pueden consultar, entre otros, J.M. RUIZ ASENCIO, De diplomática: el códice estuvo sellado, en "Leyes de Alfonso X", II: El fuero real, Ávila, 1988, pp. 152-156.

7. Los hijos como descendientes directos, junto a nietos, biznietos y demás eran considerados como herederos necesarios; "diferencia e departimiento ha entre los herederos. Ca algunos ha dellos que son Ilamados suyos del testador. E otrosy a que dizen necesarios...."; P. VI, Título III, Ley XXI.

8. "E a esta parte legitima, dizen en latin, parte debitura iure nature. E la legitima parte que deven aver los fijos es esta, que si fueren quatro o dende ayuso, deven aver de las tres partes la una, de todos los bienes de aquel a quien heredan. E si fueren cinco o mas, deven aver la mitad, e por esso es Ilamada esta parte legitima....."; P. VI, Título I, Ley XVII.

9. P. VI, Título IV, Ley XI: "Como el padre non debe poner condicion ninguna en la legitima que dexa a su fijo".

10. Ver documento $\mathrm{n}^{\mathrm{0}} 5$. 
una misma persona o familia en consonancia con el nuevo sistema de primogenitura y la formación de mayorazgos entre los miembros de la nobleza, sistema que tiende a imitarse también entre los estamentos sociales inferiores mediante la compra de tierras, base, por otro lado, del sistema económico ${ }^{11}$.

A raíz de lo anterior y en relación con ello, otra cuestión que se refleja es la pervivencia en la baja Extremadura, al menos desde el siglo XIV, de una estructura territorial de medianos y grandes latifundios formados por la concentración de tierras mediante herencia, compra o donación, siendo muchos los documentos que atestiguan esta realidad social y económica presente hasta nuestros días $^{12}$. Los avatares políticos del sur del territorio de la actual provincia de Badajoz, entregado a las Órdenes Militares o señorializado de alguna forma, favorecieron este proceso.

La jurisdicción de Jerez de los Caballeros, a la que pertenecía la heredad de Zahínos, basculó a lo largo de la Edad Media entre el realengo y el señorío de las Órdenes Militares. Desde 1283, bajo el reinado de Alfonso X, es territorio Templario, de ahí el topónimo de los caballeros ${ }^{13}$, pasando al realengo en el siglo XIV, entre 1312 y 1370 , periodo dentro del cual se data nuestro primer documento fechado en 1355. Es el primer Trastámara, Enrique II, Ilamado el de las Mercedes, el que entrega la villa y su término a la orden militar de Santiago, el 25 de diciembre de $1370^{14}$. A partir de esta fecha, más concretamente al año siguiente, en 1371, se realizan las otras dos ventas que estudiamos. Ambos documentos en su cláusula de validación corroboran perfectamente que el territorio era de la Orden Santiaguista al hacer mención al maestre en cuyo nombre el escribano escribe y suscribe los documentos ${ }^{15}$.

El proceso de señorialización continuó en parte del territorio en distintos momentos y por diversas circunstancias. Durante el siglo XV la heredad Ilamada de Zafinos con sus dehesas, tierras y demás pertenencias fue objeto de donación

11. Consultar la monografía de J.A. GARCÍA DE CORTÁZAR Y RUIZ DE AGUIRRE, La sociedad rural en la España medieval, Madrid, 1988.

12. Se puede ver el trabajo de Clemente Ramos sobre estructuras socioeconómicas medievales; J. CLEMENTE RAMOS, Estructuras señoriales castellano-leonesas: el realengo (siglos XIXIII), Cáceres, 1989, p. 115 y ss.

13. Las noticias histórica señalan que fue Alfonso IX de León, en la reconquista de Extremadura, quien hizo entrega de la plaza fuerte de Jerez a los templarios quien construyeron el castillo y la muralla de la ciudad; Diccionario geográfico de España, tomo XI, voz Jerez de los Caballeros, Madrid, 1959, p. 266.

14. Según privilegio fechado en Sevilla con esta data y mencionado por F. REDONDO GUILLÉN, Jerez de los Caballeros, Sevilla, 1981, p. 46 y ss.

15. Según Madoz la ciudad y su territorio fueron de la Orden de Santiago en su priorato de San Marcos de León. A partir del siglo XIII el territorio fue repoblado con colonos procedentes de Galicia y el valle del Jergüez, de ahí el topónimo Jerez, siendo conocido como Jerez de Badajoz; P. MADOZ, Diccionario geográfico-estadístico-histórico de España y sus posesiones de ultramar, tomo XVI, Madrid, 1850, p. 625 y ss. 
real, primero en usufructo y más tarde vitalicia ${ }^{16}$, convirtiéndose así definitivamente en territorio de señorío laico bajo el reinado de Juan II, lejos del ámbito de la influencia de las Órdenes Militares, básicamente Santiago. Más tarde la heredad de Zahínos entró a formar parte del señorío de la Casa de BélgidaMondéjar y marquesado de San Juan de Peñas Albas hasta su posterior desamortización en 1837 en que el señorío desaparece, yendo a parar a manos de particulares $^{17}$.

Dentro de este territorio, que la mayor parte del tiempo, fue de jurisdicción señorial, atestiguamos, por tanto, la existencia de una propiedad privada de mediano y gran tamaño en manos de algunas familias. Pero podemos preguntarnos, ¿como llegaron los documentos que analizamos al archivo del convento de las clarisas de Zafra, desde donde más tarde fueron desamortizados para ser propiedad estatal? Parece evidente que alguno de los últimos descendientes de la familia propietaria de estas heredades pudo donar estas tierras al convento zafrense y junto a ellas los títulos de propiedad correspondientes, ya que era habitual que las donaciones fuesen acompañadas de los correspondientes documentos notariales que aseguraban la legalidad de dichas donaciones en aras de evitar posibles y futuras reclamaciones ${ }^{18}$. Pensamos que sólo de esta forma se puede entender que dichos documentos llegasen a Zafra y no permaneciesen en Jerez de los Caballeros como villa cabeza de su jurisdicción.

\section{Las cartas de venta como documento diplomático}

La conscriptio o escrituración de los hechos o negocios jurídicos entre personas que no ejercen ni representan ninguna función pública, como las compra-ventas, constituyen una parte importante del llamado derecho notarial

16. Dentro de las donaciones medievales encontramos varios tipos en función de su contenido y objetivos. En principio en las donaciones en usufructo, denominadas también "reservato usufructu", se reservaba la propiedad legal o señorío del bien donado trasmitiendo sólo su uso o disfrute, pasando el señorío del bien donado al donatario sólo a la muerte del donante; E. SÁEZ, Colección documental del archivo de la catedral de León (775-1230), tomo I, Madrid, 1987, p. XLVIII de la introducción.

17. Sobre todas estas cuestiones se puede consultar la obra de F.L. BOBADILLA GUZMÁN, Conozco mi pueblo: Zahínos, Zafra, 1992, que sepamos la única monografía hasta el momento sobre la actual población de Zahínos y su territorio donde se mencionan algunos datos históricos y una descripción actual del pueblo y su término municipal.

18. En algunas de estas cartas de donación se incluían las Ilamadas cláusulas de tradición en las que se hacía referencia a la propiedad legal por parte del donante del bien donado mediante la entrega de los títulos de propiedad correspondientes; Ver P. OSTOS y M.L. PARDO, Documentos y notarios de Sevilla en el siglo XIII, Madrid, 1989, p. 141 y ss. En cualquier caso en las donaciones realizadas entre particulares era normal que con los bienes se entregasen también las escrituras de propiedad de los mismos; SÁEZ, op. cit., p. XL de la introducción. 
privado $^{19}$ cuyo aparición se produce a partir del siglo XIII con el surgimiento de la institución notarial y de la escritura pública que documenta hechos pri$\operatorname{vados}^{20}$. Estos hechos, en cuanto realizados entre personas particulares, dan lugar al documento privado pero con valor probatorio público que es el fin mismo por el que se redactan y elaboran ${ }^{21}$.

Las propias estructuras económicas de la baja Edad Media castellana favorecieron un mercado continuo de adquisición de bienes raíces, básicamente tierras, que constituían la base material del sistema económico. Los documentos que escrituran y dan validez legal a este hecho son las Ilamadas cartas de venta, que a partir del siglo XIII adquieren, en forma de documento notarial, sus características más principales, tal y como las conocemos a lo largo de los siglos XIV y XV y que se nos presentan en la documentación que ahora analizamos.

Los cinco documentos de venta del siglo XIV obedecen en cuanto a sus caracteres externos e internos ${ }^{22}$ a la tipología bajomedieval de las cartas de compra-venta que tienen su referencia más inmediata en el modelo diplomático recogido en Las Partidas y continuado en los formularios bajomedievales ${ }^{23}$. Precisamente es este importante código jurídico que regula, prácticamente, casi todos los aspectos de la sociedad de su época, el que ofrece, al mismo tiempo, una definición teórica clara y concisa de la acción de comprar y vender:

\footnotetext{
"Vendida, es una manera de pleyto que usan los omes entresi, e fazese con consentimiento de las partes, por precio cierto, en que se avienen, el comprador, e el vendedor" 24
}

19. Denominación de documento privado de carácter legal señalada por J. BONO HUERTA y recogida por C. MENDO CARMONA, Consideraciones sobre el concepto de documento privado, "Signo", 3 (1996), p.11-24.

20. Ver J. BONO HUERTA, Historia del derecho notarial español, tomo I, Madrid, 1979, p. 230 y ss, sobre la recepción y las fuentes legislativas del derecho notarial en Castilla.

21. Sobre la definición de documento privado en base a la diplomática y al derecho, se puede consultar MENDO CARMONA, op. cit., p. 12 y ss. También L. PASCUAL MARTÍNEZ, Estudios de diplomática castellana. El documento privado y público en la Baja Edad Media: Ios escribanos, "Miscelánea Medieval Murciana", VIII (1981), pp. 119-190.

22. Sobre este particular se puede seguir el capítulo de P.L. LORENZO CADARSO, Caracteres extrínsecos e intrínsecos del documento en, "Introducción a la paleografía y la diplomática general", edición de A. RIESCO TERRERO, Madrid, 1999, pp. 257-284.

23. El primero de ellos se redacta bajo el reinado de Enrique III y ha sido editado por G. SÁNCHEZ, Colección de fórmulas jurídicas castellanas de la Edad Media, "Anuario de Historia del Derecho Español", en adelante AHDE, 2 (1925), pp. 470-491. El resto corresponde al reinado de Juan II, siendo el más conocido y completo el Ilamado del relator, por alusión al que fuera relator, consejero, secretario y escribano de cámara de Juan II, don Fernando Díaz de Toledo, personaje clave en la cancillería real, cuyo original no se conserva, pero sí la edición impresa de Burgos de 1531; Las notas del relator con otras cosas muchas añadidas..... Cita BONO HUERTA, op. cit, p. 59 y ss. Con todo se puede ver también el artículo de J.A. ALEJANDRE, El arte de notaría y los formularios, "Revista de Historia del Derecho", Il-1 (1977-78), pp. 189-200.

24. P. V, Título V, Ley I: "Que cosa es vendida". 
Toda el título quinto de la quinta partida se dedica a establecer las condiciones en que se debían realizar las compras y las ventas, cuestión importante y que, por tanto, merece consideración especial en Las Partidas en cuanto a su mención detallada y extensión. Se trata del resultado de una sociedad en la que el comercio y las actividades comerciales empezaban a ser una parte importante de las estructuras económicas de la época. En este caso no entendemos por comercio solamente el de productos de consumo o bienes muebles, sino también el de la tierra, cuyo mercado a lo largo de todo el siglo XIII y siglos bajomedievales, empezó a adquirir una gran movilidad como resultado de unas nuevas condiciones socioeconómicas ${ }^{25}$. Las cartas de compra-venta son especialmente abundantes en las colecciones diplomáticas medievales, siendo una de las piezas más significativas de la llamada diplomática notarial privada ${ }^{26}$.

A este respecto se entiende su tratamiento teórico y el interés de las autoridades por regular dicha actividad. La ley VI del título mencionado de Las Partidas señala la forma en como se debían realizar las compra-ventas:

"Compra e vendida se puede fazer en dos maneras. La una es con carta, e la otra sin ella. E la que se faze con carta, es quando el comprador dize al vendedor, quiero que sea de esta vendida, carta fecha. E la vendida que de esta guisa es fecha maguer se avengan en el precio, el comprador, e el vendedor, non es acabada, fasta que la carta sea fecha, e otorgada, por que antes de esto puede se arrepentir qualquier de ellos. Mas después que la carta fuesse fecha, e acabada con testigos, non se podria ninguno de ellos arrepentir, nin yr contra la vendida, para desfazer la $\mathrm{l}^{\prime{ }^{27}}$.

Estas definiciones, lejos de ser meros apuntes teóricos sobre una actividad económica desarrollada, constituían la base del modelo de cartas de venta que analizaremos. Es evidente que tanto la definición de venta como la anteriormente reseñada contienen algunos de los elementos esenciales que encontraremos en el correspondiente modelo diplomático. El consentimiento de los otorgantes del hecho jurídico de la venta y el acuerdo sobre el precio son, según la definición, los dos pilares básicos de una transacción ${ }^{28}$. Resultan, pues,

25. De esta forma lo entiende Bono Huerta al considerar el notariado como una necesidad social; J. BONO HUERTA, El notariado como creación de la sociedad y su adecuación a las necesidades sociales. Indicaciones históricas, Sevilla, 1983.

26. G. NICOLAJ, Documento privato e notariato. Le origine, "Notariado público y documento privado: de los orígenes al siglo XIV. Actas del VII congreso internacional de diplomáti$\mathrm{ca}^{\prime \prime}$, II, Valencia, 1989, pp. 973-990.

27. P. V, Título V, Ley VI: "En que manera se debe fazer la vendida, e la compra".

28. Tal es así que ya en el derecho altomedieval, según el Fuero Juzgo, la venta no tenía ningún valor jurídico si no se satisfacía completamente su precio. Esta ley es de las consideradas en el Fuero Juzgo como antiguas: "E si el comprador non pagare el otra partida del precio al plazo, pague las usuras daquella partida que debe, fueras si fuere parado, que la bendición fuesse desfecha si non pagas el precio al plazo"; Fuero Juzgo, libro V, título IV: "De las cambias e de las vendiciones", ley V. Seguimos la edición del: Fuero Juzgo en latín y castellano, cotejado con los más antiguos y preciosos códices por la Real Academia Española, Madrid, 1815, p. 86. 
elementos integrantes de la acción que genera el documento y dan paso a su escrituración en forma de carta o documento con valor jurídico.

De los modelos diplomáticos de cartas de venta que encontramos en los formularios notariales castellanos bajomedievales, nos detendremos en el ofrecido por Las Partidas y en el anónimo publicado bajo el reinado de Enrique III a finales del siglo XIV, por ser el más cercano cronológicamente a la data de nuestros documentos extremeños ${ }^{29}$.

La Partida III dedica íntegramente su título XVIII a la manera y forma de elaborar distintos tipos de escrituras, reproduciendo modelos diplomáticos reales que los escribanos debían seguir en su actividad escrituradora. El modelo de carta de venta o vendida, tal y como se denomina, consta de los siguientes elementos que reproducimos en esquema ${ }^{30}$ :

\section{PARTIDAS}

\section{PROTOCOLO}

1. Intitulación

2. Dirección individual

\section{CUERPO}

1. Notificación general

2. Dispositivo

2.1. Disposición

2.2. Descripción del bien

2.3. Ubicación y linderos

2.4. Fórmula de aceptación de pago

2.5. Fórmula de precio con mención al justo precio

29. No queremos ser exhaustivos en la enumeración de formularios notariales bajomedievales en Castilla que han sido editados, sobre todo a partir del siglo XV y siglos siguientes, siendo muchos los publicados para el ámbito de la Corona de Aragón. Se puede ver L. CUESTA, Un formulario notarial castellano del siglo XV, Madrid, 1948. También J. GARCíA GRANERO, Formularios notariales de los siglos XIII-XIV, "Anales de la Academia Matritense del Notariado", 22 (1978), pp. 227-286; y F. SEVILLANO COLOM, Un nuevo formulario inédito. Siglo XIII, "AHDE", 19 (1948-49), pp. 548-589, entre otras publicaciones.

30. P. III, Título XVIII, Ley LVI: "Como debe ser fecha la carta de vendida". 


\section{Cláusulas}

3.1. Cláusula de trasmisión de dominio

3.2. Cláusula de pertenencia

3.3. Cláusula de libre disposición

3.4. Cláusula de amparo y defendimiento

3.5. Cláusula de saneamiento

3.6. Cláusula de obligación de contrato

3.7. Cláusula de sanción pecuniaria

3.8. Cláusula de obligación de personas y bienes

3.9. Cláusula renunciativa de derecho

\section{ESCATOCOLO}

\section{Data tópica y crónica}

\section{Suscripción de testigos y escribano}

Este esquema teórico e ideal es el que se propone para ser reproducido, más o menos con ligeras variantes, en todas las cartas de venta bajomedievales

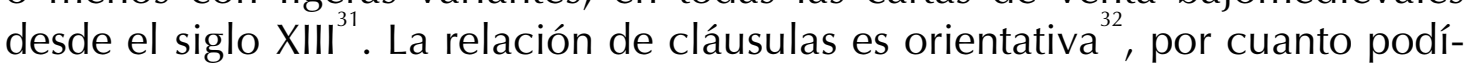
an o no aparecer en las escrituras, faltando alguna de ellas o incorporándose otras nuevas, sobre todo desde finales del siglo XIII en que los documentos pierden su tradicional sobriedad y ganan en retórica y formulismos, en un cada vez más creciente grado de tecnicidad que irá complicando su análisis ${ }^{33}$.

El mencionado anónimo formulario de época de Enrique III conocido como "Formularium Instrumentorum" destinado al uso profesional de un notario de Ávila

31. En este sentido se puede ver el trabajo de Ostos y Pardo sobre la documentación notarial sevillana del siglo XIII donde se reproduce el esquema de 67 cartas de venta de bienes inmuebles que, más o menos, se ajustan al modelo de Las Partidas; OSTOS y PARDO, op. cit., p. 103 y ss.

32. En relación a la compleja tipología de cláusulas diplomáticas y sobre su sentido y significado se puede consultar la monografía de A. TAMAYO, Archivística, diplomática y sigilografía, Madrid, 1996.

33. J. BONO HUERTA, Breve introducción a la diplomática notarial española. Parte primera, Sevilla, 1990, p. 53 y ss. Del mismo autor, La práctica notarial en el Reino de Castilla en el siglo XIII. Continuidad e innovación, "Notariado público y documento privado: de los orígenes al siglo XIV. Actas del VII congreso internacional de diplomática", I, Valencia, 1989, pp. 481-506.

34. Precisamente sobre notarios de esta ciudad se puede consultar el trabajo de B. CASADO QUINTANILLA, Escribanos de la ciudad de Ávila durante el siglo XIII, "Anuario de Estudios Medievales", en adelante AEM, 18 (1988), pp. 133-138. 
y redactado hacia finales del siglo XIV, contiene 75 fórmulas, la mayor parte referidas a documentación privada, entre las que se encuentra la referida a cartas de venta que ocupa el número 6 en el orden del códice que se guarda en la Biblioteca Nacional ${ }^{35}$. El esquema propuesto por el formulario para este tipo de documento es muy semejante al que ofrecen Las Partidas.

\section{FORMULARIO DEL SIGLO XIV}

\section{PROTOCOLO}

1. Intitulación

2. Dirección

\section{CUERPO}

1. Notificación general

2. Dispositivo

3.1. Fórmula de acceso al dispositivo de espontánea voluntad

3.2. Disposición

3.3. Descripción del bien

3.4. Ubicación y linderos

3.5. Fórmula de precio con mención al justo precio

3.6. Fórmula de aceptación de pago

3. Cláusulas

3.1. Cláusula de pertenencia

3.2. Cláusulas renunciativas de derecho

3.3. Cláusula de trasmisión de dominio

3.4. Cláusula de libre disposición

3.5. Cláusula de amparo y defendimiento

35. BN, Manuscritos, Mns. nº 10.003, según referencia de G. SÁNCHEZ en su ya citado artículo. 


\subsection{Cláusula sancional}

3.7. Cláusula de obligación de personas y bienes

3.8. Cláusula de renuncia de derechos

3.9. Cláusula de corroboración

\section{ESCATOCOLO}

\section{Suscripción de testigos}

Como se puede observar la relación de cláusulas, dentro de los elementos formales, encaminadas a sancionar el hecho jurídico de la venta es múltiple y de distinto tipo, desde las Ilamadas generales, presentes en cualquier tipo de documentación, caso de las sancionales o pecuniarias, las de obligación de bienes y la de corroboración, hasta las específicas en función del tipo documental como las de justo precio, trasmisión de dominio y libre disposición, entre otras, encaminadas a asegurar los derechos y obligaciones de los otorgantes del documento y que, por otra parte, demuestran que el documento notarial privado, al menos desde la segunda mitad del siglo XIII, había alcanzado la forma textual y diplomática que presentará a lo largo de toda la baja Edad Media.

En cualquier caso, el análisis de los dos formularios anteriores demuestra la existencia de un parecido "modus procedendi" a la hora de redactar las cartas de venta. Ambos formularios encabezan el documento con la notificación genérica: "Sepan quantos esta carta vieren", fórmula habitualmente empleada en la documentación notarial, demostrativa de la pública función que ejerce el documento ${ }^{36}$. Continua la intitulación del otorgante, en la manera propia de este tipo diplomático, a través de la partícula "como".

En Las Partidas el ejemplo de intitulación se expresa de forma objetiva, porque todo el formulario está así redactado. En el segundo caso se hace de manera subjetiva: "commo yo fulano..." y va acompañada de la filiación y vecindad, que no aparecen en el formulario de Las Partidas: "como fulano fijo de fulano vesino de tal lugar...", para continuar con el dispositivo en forma de verbo, que en el segundo formulario se acompaña de una larga glosa marginal que funciona como fórmula de espontánea voluntad ${ }^{37}$ y que, por tanto, podía o no ser

36. En la documentación notarial privada suelen aparecer dos formas distintas de expresar la notificación: "conocida cosa sea..." y la más usual: "sepan cuantos esta carta vieren". Al parecer la primera responde a un modelo arcaico frecuente en la documentación altomedieval que, evidentemente, en Las Partidas no se recoge, al contrario de la segunda forma que sí aparece; Citan OSTOS y PARDO refiriéndose a una fosilización de la lengua protocolaria, op. cit., p. 103.

37. En algunos casos esta fórmula, siempre aneja al dispositivo, se define como declaración expresa de voluntad de realizar el negocio jurídico de la venta; Ver TAMAYO, op. cit., p. 106. 
utilizada en la conscriptio. La expresión más simple de esta fórmula sería la de "otorgo y conozco", pudiendo complicarse su redacción mediante la exposición, más o menos pormenorizada, de los objetivos y motivos de dicha acción $^{38}$. En cualquier caso el dispositivo es más complejo en Partidas, adoptando su forma de dispositivo múltiple: "vende e da por juro de heredad para siempre jamas", siendo más simple en el segundo formulario en el que aparece sólo el verbo vender en primera persona.

La dirección, como sucedía con la intitulación, aparece de forma objetiva y simple en Las Partidas y con expresión de filiación y vecindad en el segundo caso. En este sentido pensamos que Las Partidas constituyen un ejemplo de formulario puramente teórico que señala ideas y su secuenciación dentro del documento, sin vocación de constituir un modelo exacto a imitar por los notarios.

La descripción del bien objeto de venta, así como su ubicación y linderos, es la habitual en este tipo de documentos, más especificada en el formulario del siglo XIV, por los motivos antes reseñados. El ejemplo seguido, en este caso, es el de unas casas ${ }^{39}$, mientras en Partidas se utilizan diversos casos de bienes tanto raíces como inmuebles, a saber, una casa, una viña, una huerta, un olivar y una heredad con mención a ubicación y linderos para la casa y extensión para el resto de los bienes raíces, aranzadas y yugadas de tierras de año y vez, haciendo referencia al sistema de rotación bienal utilizado para las labores $\operatorname{agrarias}^{40}$.

El resto del cuerpo documental, en ambos casos, es una sucesión de cláusulas sancionales o de garantía ${ }^{41}$ del negocio jurídico de la venta no siempre colocadas en el mismo orden, ni siempre las mismas, aunque la mayoría se repiten. Esto es lógico si tenemos en cuenta que Las Partidas, como se comentó, es el modelo teórico que sirvió de base para la redacción del resto de los formularios, tanto generales como locales, en el caso que nos ocupa para un notario de Ávila.

En este sentido, del conjunto de cláusulas destacamos las generales, propias de cualquier documento notarial privado, como las de obligación general,

38. En la glosa marginal del segundo formulario se dice: "non forçado nin enduzido nin costrenido nin por miedo nin por dolo nin por otro enganno alguno traido e enduzido mas certificado de todo mi derecho e con agradable coniçion e de mi libre e placentera voluntad por mi e por todos mis herederos los mis presentes herederos e advenidores por esta publica carta e por todos tiempos valedera e en alguna cosa non revocada".

39. "una morada de casas que yo he dentro en el dicho lugar en la calle que disen de tal lugar que ha por linderos de la una parte e çetera e delante las puertas de las dichas casas la calle publica del Rey..."

40. Es muy interesante el siguiente trabajo, J.L. MINGOTE CALDERÓN, Tecnología agrícola medieval en España, Madrid, 1996.

41. Así las denomina TAMAYO; op. cit., p. 92 y ss. 
sanción, renuncia de derechos y corroboración. Junto a ellas, las propias de las cartas de venta donde se trata de una transacción en la que intervienen genéricamente la propiedad plena, jurídica y legal de un bien, el dominio que se ejerce sobre el mismo en función del ejercicio de esa propiedad y el precio de la venta.

La cláusula de trasmisión de dominio es la primera del cuerpo documental en Las Partidas, mientras en el segundo formulario se utiliza la de pertenencia integrada en una declaración de entrega: "Ias quales dichas casas vos vendo segund dicho es...", apareciendo la de trasmisión algo después, lo mismo que la de pertenencia aparece en Partidas inmediatamente después de la de trasmisión.

El precio por el que se realiza la venta se coloca en todos los casos después de haber mencionado las pertenencias, usos y derechos del bien que se vende. En Las Partidas le sigue la cláusula de aceptación del precio pagado por el vendedor: " e dixo que era bien pagado de ello", lo mismo que en el otro formulario. Una vez acordado el precio y la conformidad de los otorgantes sobre el dinero a entregar, el bien pasaba a ser propiedad legal del comprador. Para ello convenía insertar la cláusula de libre disposición de dicho bien que en Partidas aparece inmediatamente después de la de aceptación de pago y en el otro formulario algo después, una vez que el vendedor había renunciado a una serie de derechos relacionados con la forma en como se debía efectuar ${ }^{42}$ y el precio del mismo $^{43}$. De esta forma el dominio del bien vendido se trasmitía total y enteramente del vendedor al comprador, sin ningún tipo de reserva del mismo, lo cual se indicaba mediante la correspondiente cláusula ${ }^{44}$.

En los dos formularios analizados se inserta después de todo lo dicho la cláusula de amparo y defendimiento por la que tanto el vendedor como sus

42. Según el formulario del siglo XIV la paga debía ser efectuada en presencia de los testigos del documento, al mismo tiempo que el comprador debería probar que efectivamente la había hecho. Según Bono Huerta la renuncia a estos derechos sobre la forma de pago fueron usuales en el siglo XIV; BONO HUERTA, Breve introducción a la diplomática, p. 68 y ss.

43. Se trata de la renuncia a la ley del justo precio, según la cual todo bien no podía ser vendido ni comprado por menos de la mitad de su verdadero valor, de forma que en caso contrario el vendedor podía, libremente y amparado por esta normativa, demandar en cierto tiempo el bien que había sido vendido y el contrato quedaba anulado. En cartas de venta sevillanas del siglo XIII las cláusulas renunciativas a los auxilios legales sobre cumplimiento del pago adoptan otras variantes, referidas básicamente a probar el hecho de que el vendedor había recibido los maravedís de la venta; OSTOS y PARDO, op. cit., p. 108.

44. En el formulario del XIV se dice: "desde oy dia en adelante que esta carta es fecha dexo e renunçio e parto de mi todo el poder e el derecho e el sennorio e la tenencia e posesion e propiedad que yo avia...e desapodero me dellas por esta carta e todas las vendo e do e entrego e apodero en ellas por esta carta a vos...". Bono Huerta señala como a partir del siglo XIII entre los rasgos distintivos están el sustituir la simple cláusula de trasferencia de dominio por la de desapoderamiento; BONO HUERTA, Breve introducción a la diplomática, p. 54 y ss. 
herederos se comprometían, no sólo a respetar el contrato de venta, no reclamando en ningún momento el bien vendido, sino a defender al comprador de toda vicisitud relativa a este hecho o evicción, compromiso que se acompañaba de la correspondiente pena pecuniaria en caso de incumplimiento, lo que en el segundo formulario se expresa como cláusula sancional.

En Partidas la cláusula de amparo y defendimiento se acompaña de la de saneamiento del bien vendido: "Otrosi dixo e otorgo el vendedor que de aqueIla cosa que vendio, nin de derecho, nin de uso, que perteneciesse a ella non avia fecho vendida, nin enajenamiento, nin empeñamiento...e que ge la faria sana en la manera, que dicho es", así como de la de obligación de contrato que viene, en cierto modo, a rematar el conjunto de disposiciones señaladas mediante la promesa de su cumplimiento.

Las últimas cláusulas del cuerpo documental, en ambos casos, se refieren a la obligación general de personas y bienes. Esta cláusula bastante usual en la documentación notarial privada, viene a ser el complemento de la de obligación de contrato en la que la simple promesa de respetar el negocio jurídico acordado se refuerza con cierta responsabilidad penal y pecuniaria por parte del vendedor, extensible también a sus herederos. La redacción de la misma así lo indica en el segundo formulario: "para lo qual ansi conplir e mantener en la manera que dicha es obligo a ello a todos mis bienes...", sin que en este caso haya obligación personal que, sin embargo, sí aparece en Partidas: "obligo el vendedor, assí mismo, e a sus herederos, e a todos sus bienes...".

La cláusula general de renuncia de derecho también aparece en ambos formularios, derecho tanto civil como eclesiástico, según el caso, así como demás privilegios, usos, fueros y costumbres que pudiesen amparar al otorgante, en una sociedad, como la medieval, organizada en estamentos privilegiados ${ }^{45}$. En el formulario del siglo XIV dicha cláusula aparece más desarrollada, con mención a posibles privilegios reales o de otro tipo que pudiesen ser presentados como prueba de defensa ante un juez. Se remata dicha cláusula con la de renuncia a la ley que prohibía, a su vez, realizar renunciaciones generales de los derechos que asistían a una persona. Esta cláusula, como remate final, tenía sentido en cuanto el otorgante previamente había renunciado expresamente a todos sus fueros.

El formulario teórico de Las Partidas termina su exposición clausular con la renunciativa general de derecho, mientras el segundo formulario que analizamos lo hace con una de corroboración, mediante la cual el otorgante resume su intención de dar validez y firmeza al hecho jurídico que se documenta.

45. Un buen estudio sobre la sociedad extremeña en el siglo XIII y sus grupos sociales, aunque referido a Cáceres, es el de CLEMENTE RAMOS, La sociedad en el fuero de Cáceres, p. 51 y ss. 
El protocolo final comienza en Partidas con la expresión de la data tópica y crónica, mediante el sistema de la Era Hispánica ${ }^{46}$, así como la presencia de los testigos y del escribano que a ruego de los otorgantes redactó y validó el documento. En el formulario del XIV un etcétera ${ }^{47}$ suple la data y la suscripción del escribano, haciéndose mención solamente a los testigos que con su presencia corroboran la carta de venta.

En lo sustancial ambos formularios coinciden en su estructura y forma de redacción en cuanto al protocolo, cuerpo documental y escatocolo, exceptuando determinadas cláusulas como la de saneamiento y obligación de contrato que aparecen en Partidas y no en el segundo formulario, así como en este último la de corroboración final.

Ello significa que Las Partidas de Alfonso X, en la segunda mitad del siglo $\mathrm{XIII}^{48}$, sirvieron de modelo teórico a muchos documentos notariales privados, no sólo las cartas de venta, coincidiendo con el desarrollo del notariado en Castilla, al mismo tiempo que suponen la introducción del derecho romano ${ }^{49}$ a través del "Ars Notariae" de Salatiel en el que, al parecer, se inspiran ${ }^{50}$. A pesar de todo, este modelo teórico no se impuso taxativamente, dejando al arbitrio de los otorgantes la forma de escribir el documento, previa comunicación al escribano, aunque respetando determinados formulismos necesarios para que la carta de venta adquiriese su condición de instrumento notarial con plena validez.

De cualquier forma, lo que parece demostrado es que el contenido del documento determinaba, en la mayor parte de los casos, la existencia de algunas cláusulas específicas. El tipo de bien vendido, así como la formas de pago que se pudieran adoptar en cada caso, sumado al interés de los otorgantes en reseñar derechos y obligaciones que podían ser importantes en cuanto a otorgar la debida validez al negocio jurídico, establecían determinados formulismos que podían estar o no presentes, según los casos.

46. Sobre los diversos trabajos de cronología existentes que tratan el cómputo de la era hispánica se puede consultar el de C. TORRES RODRÍGUEZ, La era hispánica, "Revista de Archivos, Bibliotecas y Museos", LXXIX (1976), pp. 733-756.

47. Fórmula habitualmente utilizada como abreviación de algunas cláusulas demasiado retóricas; J. BONO HUERTA, "Initia clausularum". La abreviación de cláusulas en el documento notarial, "Las abreviaturas en la enseñanza medieval y la trasmisión del saber", Barcelona, 1990, pp. 75-96.

48. Se señala este hecho no sólo en cuanto al sistema documental teórico o del instrumento público sino también en cuanto a la propia institución notarial; BONO HUERTA, Historia del derecho notarial, I, p. 245 y ss.

49. D.P. BLOK, Les formules de droit romain dans les actes privés du Moyen Age," Miscellania Medievalia in memoria de J. F. Niermeyer, Bromingen", 1967, pp. 17-28.

50. BONO HUERTA, Historia del derecho notarial, I, p. 246. También A. PETRUCCI, El notariado italiano desde sus orígenes hasta el siglo XIV, Roma, 1959. 
No entraremos ahora en más detalles sobre otros formularios o legislación posterior o contemporánea a la que venimos analizando, caso del Fuero Real ${ }^{51}$ o el Ordenamiento de Alcalá de 1348 al que haremos mención más tarde. Sin embargo también deben tenerse en cuenta como fuentes de derecho notarial, aunque el Ordenamiento alcalaíno no sea sino la corroboración legal de lo estipulado en Las Partidas.

\section{Las cartas de venta extremeñas}

Ya indicábamos en la introducción como nuestra documentación consta de cinco documentos fechados en la segunda mitad del siglo XIV, referidos a la transacción, a miembros de una misma familia, de determinadas tierras situadas en la conocida como heredad de Zahínos, en el término municipal de Jerez de los Caballeros.

Es evidente que para el periodo bajomedieval ${ }^{52}$ conocemos perfectamente la génesis y estructura de las abundantes cartas de venta que se guardan básicamente en la mayoría de nuestros archivos municipales y eclesiásticos ${ }^{53}$. De lo que se trata, pues, es de analizar si la documentación notarial privada, en este caso las cartas de venta, a raíz de los ejemplos concretos que manejamos, se ajustaba en todo o en parte a los modelos o formularios notariales teóricos de uso general en Castilla. Del mismo modo será interesante señalar cuáles eran los criterios seguidos por los escribanos locales en la redacción de este tipo de documentos y si se ajustaban o no a los modelos teóricos mencionados. Para ello agruparemos los documentos por escribanos, de forma que estudiaremos los tres primeros, relacionados con la familia del mismo escribano, para pasar a continuación a los dos últimos que presentan distinta suscripción escribanil.

\subsection{La forma de los documentos}

Todos los diplomas que analizamos tienen como materia escriptoria el pergamino de gran tamaño y son en general de una buena traza y factura. Se trata

51. J. BONO HUERTA, La legislación notarial de Alfonso X el sabio, sus características; "Anales de la Academia Matritense del Notariado", XXVII (1984), pp. 30-43.

52. A. CANELLAS LÓPEZ, El notariado en España hasta el siglo XIV: estado de la cuestión, "Notariado público y documento privado: de los orígenes al siglo XIV. Actas del VII congreso internacional de diplomática", I, Valencia, 1989, pp. 101-139.

53. Sobre este tipo de archivos, su ordenación y funcionamiento, así como los fondos y tipología documental que custodian, se pueden consultar dos obras que, hoy por hoy, resultan básicas en archivística; F. PINO REBOLLEDO, Diplomática municipal. Reino de Castilla (1474-1550), "Cuadernos de la cátedra de paleografía y diplomática", VI, Valladolid, 1972. Sobre archivos eclesiales; P. RUBIO MERINO, Archivística eclesiástica. Nociones básicas, Sevilla, 1999. 
de un pergamino de excelente calidad, blanco, terso y bien preparado, como cabría esperar en una zona, como la baja Extremadura, donde las actividades ganaderas y la industria del curtido estaban desarrolladas.

Están realizados con tinta metaloácida de color pardo y todos aparecen pautados. En los tres primeros la caja de escritura ocupa casi todo el documento, dejando apenas unos escasos márgenes laterales, mientras en los últimos el texto aparece más holgado y con todos sus márgenes bien definidos. Predomina en todos el formato apaisado frente al segundo documento escrito en vertical y uno de los de mayor tamaño. Los mismos se cierran, bien con una línea discontinua junto al "signum" ${ }^{54}$ y la rúbrica del escribano, o bien con una doble línea formando parte del trazo de estos dos antedichos elementos validatorios ${ }^{55}$.

El tipo de letra es una gótica cursiva, la llamada precortesana, muy angulosa, de módulo cuadrangular, aunque con los rasgos específicos de cada escribano. Por ejemplo los primeros documentos del escribano Vasco Yáñez presentan una morfología de las letras muy cuidada y de bello trazado, aunque con evidentes signos de evolución hacia la gótica cortesana. Sin embargo la letra de su hijo es más pesada, más tosca y presenta, en líneas generales, menos rasgos cortesanos, lo mismo que el resto de los documentos de distintos escribanos.

No se observan señales especiales y el estado de conservación generalmente es bueno, con las anomalías corrientes en documentos de tanta antigüedad. La tinta del segundo documento aparece algo borrosa por efecto de la oxidación, dificultando su lectura. También su margen derecho presenta señales evidentes de ataque por roedores. En el resto aparecen algunas manchas amarillentas provocadas por la humedad y otras más pequeñas por la actividad de los insectos que, sin embargo, no estorban la lectura, ni afectan genéricamente a su apariencia. Señalar, por último, que todos los pergaminos llevan su correspondiente trascripción en forma de traslados notariales ${ }^{56}$, realizados por el escribano de Jerez, Juan Escudero, en papel sellado y fechados en $1703^{57}$.

54. O. VALLS SUBIRÁ, El "signum" notarial, "Centenario de la Ley del Notariado", II, Barcelona, 1963, pp. 1-143.

55. Es interesante el trabajo de A. RIESCO TERRERO, Suscripciones, signaturas y signos validativos de la documentación antigua, medieval y moderna. Origen, tipología, significado y valor, "Hidalguía", 256-57 (1996), pp. 427-445.

56. Hemos comprobado que existen evidente errores de trascripción en estos traslados notariales como el transcribir sistemáticamente Díaz en vez de Domínguez del apellido de uno de los compradores y de otras personas.

57. Resulta curiosa la leyenda exterior del sello estampado utilizado en la documentación notarial donde se dice que el coste fue de 2 maravedís para pobres de solemnidad, haciendo alusión a las monjas clarisas que custodiaban estos documentos, consideradas como pobres. De hecho las anotaciones externas de estos documentos se refieren a ellas como "mongitas". 


\subsection{La génesis documental}

La primera carta de venta (documento $\mathrm{n}^{-}$1) se data en la era de 1393, es decir el año 1355. Ésta como la siguiente, datada en septiembre de 1371 y referida al documento no 2 aparece suscrita por el mismo escribano, Vasco Yáñez. El documento $n^{\circ}$ 3, de octubre de 1371, aparece suscrito por el escribano Vasco Yáñez Cordero, suponemos que hijo del anterior, por cuanto emplea distinto signo escribanil. Esto puede suponer dos cosas. Que a pesar de la patrimonialización del oficio, el hijo podía ejercer su propia actividad notarial junto al padre sin esperar a que se produjese la correspondiente vacante, o que mes y medio después de redactarse el documento $\mathrm{n}^{\circ} 2$, a primeros de septiembre de 1371, Vasco Yáñez hubiese cesado ya como escribano de Jerez sucediéndole el hijo. Por ahora no podemos pronunciarnos en cuanto no conservamos documentos del primer escribano posteriores a estas fechas y, por tanto, desconocemos si continuó o no con su labor escrituradora, aunque la segunda hipótesis parece la más lógica ${ }^{58}$.

Sobre la identidad de esta familia de escribanos ${ }^{59}$ el propio tenor documental nos señala, en primer lugar, que Vasco Yáñez es, sin más, escribano público de Jerez de los Caballeros en el documento $\mathrm{n}^{\mathrm{o}} 1^{60}$, mientras que en los dos documentos de 1371 se especifica que ambos, padre e hijo, son escribanos del maestre de Santiago ${ }^{61}$, que en el documento $\mathrm{n}^{\mathrm{O}} 2$ se dice ser expresamente don Fernando Osórez .

Ello significa que el cambio de jurisdicción de Jerez de los Caballeros de realengo a señorío no repercutió en la situación de los escribanos que ya ejercían como tales en la villa y su territorio ${ }^{63}$. Como ya señalábamos en la introducción,

58. E. CORRAL GARCíA, El escribano de concejo en la Corona de Castilla, siglos XI-XVII, Burgos, 1987.

59. La figura del escribano concejil en Cáceres aparece descrita como un personaje que realizaba diversas funciones, aparte de la notarial, no recibiendo una retribución fija; CLEMENTE RAMOS, La sociedad en el fuero de Cáceres, p. 99 y s.

60. Es probable que fuese nombrado por Pedro I como escribano del concejo de Jerez de los Caballeros, ya que no figura entre los escribanos reales de esta cancillería, aunque su nombramiento pudo haber sido hecho también por Alfonso XI; Ver L. PASCUAL MARTíNEZ, Notas para un estudio de la cancillería castellana en el siglo XIV. La cancillería de Pedro I (1350-1369), "Miscelánea Medieval Murciana", 5-6 (1980), pp. 192-243.

61. Un excelente trabajo sobre diplomática de órdenes militares, aunque no referido a Santiago, es el de B. CASADO QUINTANILLA, Corona de Castilla: documentos de la Orden de Calatrava expedidos durante los tres últimos maestrazgos (1445-1489). Estudio diplomático, Madrid, 1997.

62. Este maestre aparece citado en F. DE RADES Y ANDRADA, Crónica de la Orden y cabaIlería de Santiago en la cual se trata de su origen y suceso y notables hechos en armas de los maestres y caballeros de ella, Valencia, 1993. Se trata de la reproducción de la edición de Toledo de 1572.

63. Sobre escribanos ver M.J. ÁLVAREZ-COCA GONZÁLEZ, La figura del escribano, Boletín de la "ANABAD", XXXVII-4 (1987), pp. 555-564. 
Jerez era de realengo todavía en el año 1355, fecha del primer documento, pasando a la Orden de Santiago en 1370 por donación de Enrique II ${ }^{64}$. Esto supone que los nombramientos reales de escribanos para Jerez fueron respetados por el nuevo maestre de Santiago. Lo que desconocemos es si la nueva jurisdicción maestral procedió a nuevos nombramientos. Lo que sí sabemos es que Fernando Osórez fue maestre de Santiago entre 1371 y 1383 sirviendo a Enrique II en diversas circunstancias ${ }^{65}$.

En cuanto a los vendedores son distintos frente a los mismos compradores, Gonzalo Domínguez y Teresa Yáñez, su mujer, que en distintos momentos y circunstancias van adquiriendo una serie de tierras colindantes, cuyo fin, como se señaló, será ampliar su patrimonio territorial inicial. Nos encontramos, pues, con que una parte de los otorgantes son siempre los mismos.

Señalar que en la documentación de carácter privado es, en ocasiones, difícil determinar la actio. En este caso se presupone un acuerdo tácito entre los otorgantes sobre el negocio jurídico de la venta. El otorgamiento del mismo precede siempre a la "iussio" en forma de declaración de voluntad: "Y porque esto sea firme y valedero para en todo tiempo y no venga en duda, nos los dichos vendedores de suso nombrados otorgamos esta carta..." ${ }^{66}$. Como se observa la cláusula de corroboración, que cierra el conjunto de las cláusulas del cuerpo documental, lleva implícita la otorgación que se hace ante el escribano y los testigos presentes en la conscriptio.

De este modo ésta se inicia con el otorgamiento que antecede a la "iussio" notarial de los vendedores en forma de "rogatio": "rogamos y mandamos al dicho Vasco Yáñez, escribano, que escribiese esta carta y la diese a vos los dichos compradores signada con su signo ${ }^{\prime 67}$.Conviene destacar que en el formulario de Las Partidas la "iussio" aparece realizada por las dos partes otorgantes del documento, es decir, compradores y vendedores, mientras en los modelos que analizamos solamente se cita a los vendedores tanto otorgando como trasmitiendo el mandato de escrituración.

A su vez otorgamiento e "iussio" aparecen de nuevo juntos en la validación: "esta carta por ruego y otorgamiento de los sobre dichos escribí e

64. M. GARRIDO SANTIAGO, Documentos de la orden de Santiago sobre castillos extremeños, Cáceres, 1989.

65. Lo que conocemos sobre este personaje nos lo relaciona con los acontecimientos bélicos de su época. Sabemos que se puso del lado de los intereses trastámaras apoyando a Enrique II, cuando en Carmona luchó contra el caballero Martín López de Córdoba que se había rebelado, probablemente por apoyar al bando del asesinado Pedro I. También en Lisboa peleó con los caballeros de Santiago lo que le valió una transitoria excomunión y posterior absolución papal; P.A. PORRAS ARBOLEDAS, La orden de Santiago en el siglo XV. La provincia de Castilla, Madrid, 1997, p. 24.

66. Ver documento $\mathrm{n}^{\mathrm{o}} 2$.

67. Ver escatocolo del documento $\mathrm{n}^{\circ} \mathbf{1}$. 
hice aquí mio signo a tal ${ }^{\prime \prime^{68}}$. La misma expresa que el documento ha sido escrito y suscrito a intención de los vendedores y por su ruego o mandato, actuando el notario de simple fedetario público para que dicha intención y mandato adquieran la correspondiente fuerza legal de instrumento públi$\mathrm{CO}^{69}$.

Del mismo modo, en todos los casos, la aparición de testigos confirmantes o instrumentales contribuye a manifestar la fuerza pública de los documentos. Los testigos se dice estar presentes en la conscriptio junto al notario, sin que se mencione la presencia de los otorgantes, que no están presentes. En el documento $\mathrm{n}^{\mathrm{o}} 1$ dicha realidad es manifestada por el propio escribano que estuvo presente con los testigos y sólo en el documento $\mathrm{n}^{\mathrm{o}} 2$ se dice además que fueron llamados para ello. De nuevo la actuación del escribano, precisamente por ser pública, debía ser testimoniada por los testigo, apareciendo él mismo también como testigo del hecho.

Señalar que no se expresa en estos documentos "recognitio" alguna y que la datación crónica es a través de la Era Hispánica con mención de mes y día, mientras la tópica señala la villa de Jerez, sin más.

Ya comentamos anteriormente algo sobre la validación en la que suscribe Vasco Yáñez y se relacionan los testigos. Conviene destacar que en los tres documentos aparecen siempre siete testigos, aunque nunca los mismos, algunos de ellos mencionados como escribanos. En el documento $\mathrm{n}^{\mathrm{o}} 2$ se dice que aparte de los reseñados participaron otros. A este respecto no hemos encontrado en Partidas ni en el formulario del siglo XIV ninguna mención concreta al número de testigos. En el primer caso se dice: "testigos Ilamados e rogados fulano, e fulano", pero creemos que, en este caso, lejos de ser una expresión vaga y genérica significa no que tuviera que haber sólo dos testigos. Más bien pensamos que este número era el mínimo imprescindible de personas que debían corroborar con su presencia la escrituración del negocio jurídico. En el segundo formulario solamente se menciona que debía haber testigos presentes.

Los dos últimos documentos se fechan por el estilo de la Natividad del año 1400. Uno el 19 de abril (documento $\mathrm{n}^{\mathrm{o}} 4$ ) y el siguiente el 7 de mayo (documento $\mathrm{n}^{\mathrm{o}}$ 5), aunque, como hemos señalado, de escribano distinto, Ferrand Álvarez el primero y Gonzalo Vázquez el segundo.

68. Ver escatocolo del documento $\mathrm{n}^{\underline{0}} 1$.

69. M.J. ÁLVAREZ-COCA GONZÁLEZ, La fe pública en España. Registros y notarías. Sus fondos, organización y descripción, Boletín de la "ANABAD", XXXVII (1987), pp. 7-67; p. 7 y ss donde ofrece varios conceptos de fe pública, entre ellos la fe pública notarial, en el que la misión del notario es conferir autenticidad a los contratos y convenciones extrajudiciales de derecho privado mediante su autorización como funcionario público. 
Su génesis es semejante al la de los documentos anteriores, en cuanto el otorgamiento de los vendedores inicia la conscriptio, ya que se dice que otorgan el hecho jurídico en presencia del escribano, rogándole escriba el documento. Este otorgamiento se repite de nuevo en la validación final, excepto en el $\mathrm{n}^{-} 5$, donde no se señala. Del mismo modo dicho otorgamiento precede siempre a la "iussio".

Sólo en el documento $\mathrm{n}^{\mathrm{0}} 5$ se señala la jurisdicción maestral del escribano, frente al $n^{0} 4$, que es el único de los cinco documentos que analizamos, donde se define al escribano como notario público de Jerez, pero sin señalar bajo qué jurisdicción, que suponemos la maestral. En cuanto a los testigos en el documento $\mathrm{n}^{\mathrm{O}} 4$ aparecen tres y en el otro cinco, todos ellos presentes, Ilamados y rogados, junto al propio escribano que actúa también de testigo.

La validación se cierra con la rúbrica y el signo del escribano, fundamentales para que los documentos adquieran su verdadero valor legal y de prueba jurídica. El signo de los dos primeros documentos del escribano Vasco Yáñez se dibuja en forma de rombo de cuatro largas puntas con un círculo en su interior dividido en cuatro partes y acompañado a su vez de otras señales. El signo de su hijo representa un doble cuadrado dividido en dos partes y rodeado de señales búclicas.

Los dos últimos documentos Ilevan signos parecidos. Básicamente el del escribano Ferrand Álvarez es en forma de doble cuadrado dividido en su interior en dos secciones a través de una línea oblicua, apareciendo en el de Gonzalo Vázquez el mismo tipo de cuadrado pero con una cruz gamada en su interior.

\subsection{Estructura diplomática}

Conviene ahora analizar si nuestros documentos se ajustan a los modelos teóricos establecidos. El grueso de los documentos que analizamos presenta el mismo protocolo que los modelos de formularios ya expuestos ${ }^{70}$ : intitulación y dirección. Comentar que la intitulación es la usual en este tipo de documentos privados con expresión, en todos los casos, de la vecindad de los otorgantes. Sólo señalar que en todos menos uno el topónimo Jerez va acompañado de la expresión, "cerca Badajoz" sin duda para distinguir esta villa extremeña de su

70. Sobre formularios medievales se puede ver, A. GARCíA GALLO, Los documentos y los formularios en España hasta el siglo XIII, "Anales de la Academia Matritense del Notariado", 22 (1981), Homenaje al Sr. D. Rafael Núñez Lagos, I, pp. 113-177.

71. Así se expresa también en otros documentos medievales, según el título de la siguiente obra basado en algunos libros de visitas del siglo XV; E. MÉNDEZ VENEGAS, Xerez cerca de Badajoz y sus valles: siglo XV, Badajoz, 1998. 
homónima andaluza ${ }^{72}$, ya que ambas poblaciones castellanas habían adquirido importancia en el siglo XIV. Tan sólo en dos de los documentos, los números 2 y 3 , se cita la profesión del comprador, señalando que Gonzalo Domínguez era escribano, omitiéndose este dato en el número 1 donde participa el mismo otorgante.

Un dato interesante es que en ninguno de los documentos aparece la fórmula de esposo consentimiento, habitual en la documentación notarial privada cuando los otorgantes son cónyuges. En este caso marido y mujer actúan por ambas partes otorgantes de mutuo acuerdo y en la misma igualdad, siendo realidad que en algunos casos la propietaria de la heredad es la esposa, según señala la cláusula de tradición presente, caso del documento no 4 .

Lo que más nos interesa es fijarnos en el cuerpo documental. Los modelos teóricos expresan la fórmula de acceso al dispositivo, el dispositivo como tal, la descripción del bien, su ubicación y linderos. Comprobamos que todos los documentos adoptan este esquema, incluyendo la mayoría la cláusula de tradición sobre la manera en como los vendedores habían recibido sus respectivas propiedades, la mayoría por herencia entre los mismos parientes. A raíz de esto conviene comentar la legislación foral castellana recogida en el Fuero Viejo de Castilla sobre la manera en como se podían vender las heredades, estipulando que nadie pudiese enajenar la parte de su herencia hasta haber sido recibida o heredada, a excepción de las ventas realizadas entre hermanos ${ }^{73}$.

La fórmula del precio menciona distintas modalidades de pago, en dinero sólo o en dinero y especie, como la entrega de determinados animales ${ }^{74}$ o una casa $^{75}$, siempre con expresión del tipo de moneda, maravedís y cruzados y su

72. Téngase en cuenta que en la documentación medieval aparece Jerez, sin más, ya que lo de los Caballeros se añadió después por los motivos históricos apuntados en la introducción; Ver REDONDO GUILLÉN, op. cit. Resulta interesante la mención a Badajoz, frente a otras ciudades del territorio, que actuaba como punto de referencia de las poblaciones cercanas; Se puede consultar la obra de A. GONZÁLEZ RODRÍGUEZ, Historia de Badajoz, Badajoz, 1999, p. 115 y ss. sobre el Badajoz de época cristiana. Para el periodo musulmán es interesante el trabajo de Clemente Ramos donde se habla de la fortaleza de Jerez en la línea defensiva de las estribaciones montañosas del sur de Badajoz situada sobre una importante vía de comunicación en la ruta Badajoz Córdoba-Sevilla y cuyo fin era proteger los pasos hacia el valle medio y bajo del Guadalquivir. El recinto amurallado tenía 14,4 hectáreas, siendo el alcázar de época cristiana aprovechando el antiguo trazado musulmán; J. CLEMENTE RAMOS, La Extremadura musulmana (1142-1248). Organización defensiva y sociedad, "AEM", 24 (1994), pp. 647-701, p. 682 y ss.

73. "Que ninguna eredat que eredan parientes, ninguno puede vender la sua suerte a ningund pariente, nin a otro ome fasta que la aya partido, sino ermano a ermano. Vale lo que es vendido a ermano, ante que sea partido, mas non le puede vender a otros parientes a menos de ser partido, e si de otra guisa lo vendier la venta non vale por el fuero; Fuero Viejo de Castilla, libro IV, título I, caps. VIII y XI: De las vendidas, e de las compras; edición de la editorial Lex Nova de I. JORDÁN DE ASSO DEL RÍO y M. DE MANUEL RODRÍGUEZ, Madrid, 1771, pp. 105 y 106.

74. Ver documento $\mathrm{n}^{\mathrm{O}} \mathbf{1}$.

75. Ver documento $\mathrm{n}^{\mathrm{O}} 2$. 
equivalencia, teniendo en cuenta que el maravedí era sólo una moneda de cuenta, según suele ser costumbre en estos documentos. En el último documento la entrega de los maravedís se debía hacer a la persona a quien el vendedor debía la compra de un caballo. La mención al justo precio tal y como aparece en los formularios no se hace en los documentos del escribano Vasco Yáñez y sí en el resto, con la tradicional fórmula de donación de la demasía, si el bien más precio valiere. A este respecto la única ley que el Ordenamiento de Alcalá de 1348 dedica a las ventas se refiere precisamente al hecho de no ser válida transacción alguna realizada por más o por menos de su precio verdadero $^{76}$, de ahí la necesidad de incluir la cláusula de donación de la demasía antes mencionada con el fin de no contradecir la ley, así como la renuncia expresa al amparo que proporcionaba la misma.

En todos, menos en un caso, documento $\mathrm{n}^{\circ}$ 2, se expresa la aceptación del pago por los vendedores. Señalar que la ley establecía que el pago debía hacerse en presencia del escribano y los testigos y así lo recogen Las Partidas, por lo que, en caso contrario, se hacía necesaria la correspondiente renuncia a este derecho mediante la cláusula de "la pecunia non contada", tal y como aparece en todos los documentos ${ }^{77}$. Sólo en el documento $n^{0} 2$ no se menciona dicha renuncia por cuanto en la validación el propio escribano dice haber presenciado como los vendedores recibieron el dinero de la paga.

El apartado de cláusulas de la "sanctio" es el que más diferencias pude ofrecer. Nos fijaremos en primer lugar en aquellas referentes al bien objeto de la venta, todas ellas aparecen complementándose. La de derechos y usos pertenecientes al bien vendido, generalmente unida a la de saneamiento, trasmisión del dominio y libre disposición aparecen siempre, según los modelos descritos. Tan sólo en el formulario del siglo XIV no se menciona la de saneamiento como cláusula obligativa mediante la cual los vendedores se comprometen a entregar el bien libre de cargas anejas a su naturaleza jurídica. Esta cláusula por la que se garantizaba la total y libre enajenación y consiguiente disposición del bien se suele acompañar también de la cláusula de obligación de defendimiento, generalmente judicial, por la parte vendedora en caso contrario a lo estipulado.

La autosanción del vendedor era una forma de obligación pecuniaria que ratificaba dicho defendimiento. Dicha sanción, siempre en dinero, consistía en el doble del precio de venta, más todas aquellas costas que el proceso pudiese

76. Ordenamiento de Alcalá, Título XVII, ley única: "De las vendidas, e de las compras. Como se puede desfaçer la vendida ò la compra, quando el vendedor se dice engannado en el prescio"; edición de la editorial Lex Nova de I. JORDÁN DE ASSO DEL RíO y M. DE MANUEL RODRÍGUEZ, Madrid, 1774, p. 27.

77. J.A. ARIAS BONTES, Sobre la "querela" y la "exceptio non numeratae peccuniae". Derecho romano y vicisitudes medievales, "AHDE", 53 (1983), pp. 107-136. 
generar, con el compromiso, en cualquier caso, de cumplir el contrato. Esta cláusula penal podía aparecer inserta en la anterior o independiente, en el sentido de colocada en otro lugar de la "expositio"

Señalar la importancia que siempre se da a la cláusula de trasmisión de dominio mediante determinadas expresiones relativas al desapoderamiento de la propiedad, tenencia o señorío y el apoderamiento a los compradores, que son las mismas que aparecen en los documentos notariales específicos que se redactaban para dar testimonio de estas trasmisiones, las cuales revestían todo un ceremonial cargado de ritos y gestos simbólicos muy interesantes para conocer las mentalidades del mundo bajomedieval ${ }^{79}$.

Tanto Las Partidas como el formulario anónimo incluyen en sus modelos teóricos la cláusula renunciativa general de derechos que como tal aparece en los cinco documentos que estudiamos, complementada, en algunos casos, con la de renuncia, a su vez, a la ley que prohibía renunciar a dichos derechos y que podemos denominar renunciativa a la renuncia general de derechos. En las mismas casi siempre se utilizan similares expresiones, como se puede observar en el apéndice documental, relativas, en el primer caso, a la idea de prescindir de cualquier auxilio legal, civil o eclesiástico, según el fuero de cada persona, incluyendo además el derecho a la defensa reconocido por la ley a todas las personas.

También la cláusula de obligación general de personas y bienes aparece como forma de sanción del contrato. Junto a todas ellas, la cláusula de corroboración final, que no se cita en Partidas, y que aparece en todos los documentos. Esta cláusula lleva implícita casi siempre la correspondiente "iussio" notarial en forma de ruego, así como el anuncio de validación con mención al signo ${ }^{80}$.

Con todo, se puede afirmar que el modelo teórico de cartas de venta propuesto por Las Partidas, e inspirado en la legislación, se mantuvo en los formularios notariales locales para uso de los escribanos y que verdaderamente estos hicieron uso del mismo, exceptuando determinados aspectos de contenido específico propios de cada negocio jurídico y teniendo en cuenta, además, que los otorgantes eran los que en último término decidían el contenido de los documentos, aunque siempre respetando los formulismos necesarios.

78. F. MATEU Y LLOPIS, Las cláusulas penales pecuniarias de los documentos para la historia de las instituciones de León y Castilla (siglos X-XIII), "AHDE", 23 (1953), pp. 579-591.

79. A este respecto se puede consultar mi trabajo sobre documentos madrileños del siglo XV de traspaso de propiedad legal o de usufructo de ciertos bienes inmuebles y raíces; T. PUÑ AL FERNÁNDEZ, Ritos y símbolos socioeconómicos de una comunidad medieval, "Medievalismo", 7 (1997), pp. 77-98.

80. R. NúÑEZ LAGOS, Estudios sobre el valor jurídico del documento notarial, "Anales de la Academia Matritense del Notariado", I, 1945, pp. 379-510. 
Esta teoría se confirma si tenemos en cuenta que no se observan demasiadas diferencias entre los documentos de distintos escribanos, aunque hay que señalar que el documento $n^{-}$3, redactado por el hijo de Vasco Yáñez, aparece más desarrollado que el resto en cuanto a su estructura clausular, resultando por ello más complejo, hecho curioso si pensamos que de todos es el que presenta una escritura y aspecto más toscos.

En cuanto a las dos primeras cartas de venta del mismo escribano, no son idénticas en su contenido, como parece lógico, pero sí semejantes en cuanto a su estructura, aunque las cláusulas no siempre aparezcan en el mismo orden, faltando sólo alguna de ellas, siempre en función del contenido del documento. A raíz de lo cual podríamos preguntarnos, ¿seguían los escribanos al pie de la letra el contenido de los formularios?.

Parece que la respuesta es afirmativa en el caso de aquellas cláusulas sancionales y corroborativas del hecho jurídico y siempre, como decimos, en función del contenido del documento, no sucediendo así con el resto. En cualquier caso la práctica notarial habitual del escribano suponía un conocimiento, a la par que dominio, de la estructura de los documentos, siempre determinada por su contenido y el deseo de las partes, de ahí las distintas versiones de un mismo tipo diplomático que, como tales, no afectan como tal a su definición, pero que merece la pena ser estudiadas en aras de obtener un mejor conocimiento para una época concreta de determinadas tipologías diplomáticas, en este caso las cartas de venta.

\subsection{Estructura analítica documental}

Una vez estudiada la estructura diplomática de nuestros documentos extremeños, conviene realizar el correspondiente análisis documental, señalando y desentrañando cada una de sus partes, con el fin de tener una visión clara y manifiesta de una tipología diplomática, como las cartas de venta, ampliamente representada en la documentación notarial privada castellana de la Edad Media.

Los documentos van ordenados cronológicamente y se acompañan de la regesta, trascripción y el correspondiente análisis documental. Lejos de parecer repetitivos, creemos que la inserción de los respectivos análisis resulta conveniente por cuanto cada documento se configura como una realidad independiente por su contenido, aunque inserta por su estructura básica en una misma tipología. En este caso pensamos que no sólo la estructura define tipos documentales sino también el contenido.

Las normas de trascripción son las usuales en estos casos, con actualización de signos ortográficos, nombres propios, topónimos y determinados verbos, aunque respetando, siempre, las expresiones y estructura original de cada texto. 
En este caso algunas palabras se han trascrito tal cual con el fin de no desvirtuar su sentido.

AHN, Clero, carp. $46, n^{-} 7$ bis

1355, julio, 22. Jerez

Alfonso, tendero y su esposa Luisa Domínguez, vecinos de Jerez de los Caballeros, venden a Gonzalo Domínguez y su esposa Teresa Yáñez, vecinos del lugar, la mitad de una heredad en Zahínos por 1.500 maravedís. Ante Vasco Yánez, escribano.

Carta de venta. Original. Manuscrito. Castellano. 1 f.r. 28,5 x 23 cms. Pergamino. Precortesana. B (con manchas de humedad y algunas de insectos)

Sepan cuantos esta carta vieren como yo Alfonso, tendero y yo Luisa Domínguez, su mujer, hija de Domingo Zurame, vecinos que somos de Jerez, cerca Badajoz, conocemos y otorgamos que vendemos a vos Gonzalo Domínguez y a Teresa Yáñez, vuestra mujer, vecinos de la dicha villa, la mitad de una heredad que nos habemos en término de la dicha villa, donde dicen Zahínos, que fue la dicha heredad del dicho Domingo Zurame, padre de mí la dicha Luisa Domínguez. Que ha por linderos toda la dicha heredad de que vos vendemos, la mitad heredad que fue de Bartolomé Xalmillo por las Lageas y por el Zorrar de Meas y por el Espinero y por cima del Tremedal y como va consigo dar en la dehesa de Zahínos y como parte por el rasero de Zahínos por unos villares y va dar consigo en el Arroyo del Judío y con heredad de Vasco González Gallego por la mitad del agua y como va ahí parte con Vicente Miguel por la mitad del agua del Arroyo del Judío. La cual dicha mitad de heredad vos vendemos por precio nombrado que de vos recibimos, que son mil y quinientos maravedís de blancas de esta moneda usual, que hacen diez dineros el maravedí. Los cuales maravedís recibimos de vos en enplegos en esta manera: veinte puercos y puercas mayores, machos y hembras y siete vacas paridas y dos novillos que yo el dicho Alfonso, tendero, de vos recibí en precio de mil y doscientos maravedís y trescientos maravedís en dineros que nos disteis y pasaron a nuestro poder en presencia de Vasco Yáñez, escribano público aquí en Jerez por nuestro señor el rey, y ante los testigos de esta carta. Así que somos entregos y pagados de los dichos mil y quinientos maravedís que nos no fincó ninguna ni alguna cosa por pagar. Y renunciamos la ley del derecho que dice que los testigos de la carta deben ver hacer la paga de dineros contados o de cosa que los valga y la otra ley del derecho que dice general renunciación no valga sobre sí al cual que la carta otorga, especialmente la renuncia. Y otrosí renunciamos la ley de la excepción de los maravedís no contados ni vistos ni dados ni recibidos, que no podamos decir nos ni alguno de nos ni otro por nos que los de vos no recibimos y si lo dijésemos que nos no valga ni nos sea recibido en juicio ni fuera de él. Y desde hoy día que esta carta es hecha en adelante nos los dichos vendedores nos partimos y desapoderamos de la tenencia y propiedad y posesión y señorío 
que nos habemos en la dicha mitad de heredad y por esta carta apoderamos a vos los dichos compradores en la dicha tenencia y propiedad y posesión y señorío. Y vos damos cumplido poder que la entréis y la tengáis por vos y para vuestros herederos con entradas y con salidas y con todas sus pertenencias y usos y derechos que le pertenecen y pertenecer deben de hecho y de derecho, libres y quitas, desembargadamente para todo siempre jamás. Para vender y dar y donar y trocar y cambiar y enajenar y para que hagáis de ella y en ella todo lo que vos quisiereis así como del vuestro haber propio que habéis de compra y de justo título. Y otrosí nos los dichos vendedores otorgamos la dicha tenencia y propiedad y señorío que nos habemos en la dicha mitad de heredad ni por razón de usos ni de derechos que a ella pertenezcan que no habemos de ella hecho vendida ni enajenamiento ni trueque ni cambio ni otro enajenamiento a otra persona alguna. Antes prometemos a buena fe y sin todo mal engaño que nos la amparemos y defenderemos y haremos sana a todo tiempo de cualquier embargo que vos sobre ella viniere, así en juicio como fuera de él, so pena del doblo del precio sobre dicho y del mejoramiento si fuere hecho y de las costas. Y obligamos nos a todo en que pagada o no la dicha pena todavía que valga y sea firme esta dicha vendida con todo cuanto en esta carta se contiene para todo siempre jamás. Y para todo esto que dicho es tener y cumplir y para pagar la pena si en ella cayéremos, obligamos a nos mismos y a todos nuestros bienes muebles y raíces, ganados y por ganar. Y sobre todo esto renunciamos y quitamos de nos y de todos nuestros bienes toda ley y todo fuero y todo derecho escrito $y$ no escrito y quitamos nos de toda excepción y de todas las otras buenas razones y defensiones que por nos hayamos o podamos haber que contra esto sea. Otorgamos que nos no valga ni nos sean oídas, ni recibidas en juicio ni fuera de él. Por que todo esto sea firme y valedero nos los dichos Alfonso, tendero, y Luisa Domínguez, su mujer, otorgamos todo esto que dicho es y rogamos y mandamos al dicho Vasco Yáñez, escribano, que escribiese esta carta y la diese a vos los dicho compradores signada con su signo. Hecha en Jerez, a veinte y dos días de julio, era de mil y trescientos y noventa y tres años. Testigos Alfonso Gorjón, Salvador Estévez Veguilla, Pedro Alfonso, hermano de Gil Alfonso de la Higuera, Cristóbal Martínez, alfayate, Martín Gallego, criado de Andrés Fernández. Y yo Vasco Yáñez, escribano público sobre dicho, a esto que dicho es presente fui con los dichos testigos y esta carta por ruego y otorgamiento de los sobre dichos escribí e hice aquí mío signo que tal (signum) es. (rúbrica).

\section{Estructura documental \\ PROTOCOLO}

1. Intitulación: Alfonso, tendero y su esposa Luisa Domínguez, hija de Domingo Zurame, vecinos de Jerez de los Caballeros.

\footnotetext{
2. Dirección: Gonzalo Domínguez y su esposa Teresa Yáñez, vecinos del lugar.
} 


\section{CUERPO}

1. Notificación: Es de tipo general. "Sepan cuantos esta carta vieren".

2. Dispositivo

2.1. Acceso al dispositivo: "Conocemos y otorgamos".

2.2. Disposición: "Vendemos".

2.3. Tipo de bien con ubicación y linderos: La mitad de una heredad en Zahínos.

2.4. Fórmula de tradición: Heredad que fue de Domingo Zurame, padre de Luisa Domínguez.

2.5. Precio: Expresado en maravedís y su equivalencia en blancas y dineros.

2.6. Fórmula de pago: En dinero y especie (ganado porcino y vacuno).

2.7. Fórmula de aceptación de pago: "Que nos disteis y pasaron a nuestro poder... y somos entregos y pagados... que nos no fincó ninguna ni alguna cosa por pagar".

\section{Cláusulas}

3.1. Cláusula de pago : "Renunciamos la ley del derecho que dice que los testigos de la carta deben ver hacer la paga...".

3.2. Cláusula renunciativa específica de derechos : "Renunciamos... la ley del derecho que dice que general renunciación no valga...".

3.3. Cláusula de renuncia a la pecunia non contada: "Renunciamos la ley de la excepción de los maravedís no contados ni vistos ni dados ni recibidos...".

3.4. Cláusula de trasmisión de dominio: "Y desde hoy día... nos los dichos vendedores nos partimos y desapoderamos... y por esta carta apoderamos a vos los dichos compradores...".

3.5. Cláusula de libre disposición: "Y vos damos cumplido poder que la entréis y la tengáis por vos... para vender y dar, etc...".

3.6. Cláusula de saneamiento: "Que no habemos hecho vendida, ni enajenamiento, ni trueque ni cambio...".

3.7. Cláusula de defendimiento con sanción: "Que nos la amparemos y defenderemos.... so pena del doblo del precio... y del mejoramiento si fuere hecho y de las costas".

3.8. Cláusula de obligación general de personas y bienes: "Obligamos a nos mismos y a todos nuestros bienes muebles y raíces ganados y por ganar". 
3.9. Cláusula renunciativa de derechos: "Renunciamos y quitamos de nos y de todos nuestros bienes toda ley y todo fuero y todo derecho escrito y no escrito, etc...".

3.10. Cláusula de corroboración: "Por que todo esto sea firme y valedero nos los dichos... otorgamos esto que dicho es".

\section{ESCATOCOLO}

1. Data: Lugar, día, mes y año por el sistema de la Era Hispánica.

2. Suscripción de testigos: Simple enumeración de los mismos.

3. Suscripción del escribano: Con cláusula de refrendo con el nombre del escribano, "Yo Vasco Yáñez...", seguida de la "iussio" notarial, el signo escribanil y la rúbrica.

AHN, Clero, carp. 46, no 9

1371, septiembre, 1. Jerez

Vicente Miguel, hijo de Miguel Arias y su esposa María Alfonso, vecinos de Jerez de los Caballeros, venden a Gonzalo Domínguez, escribano y su esposa Teresa Yáñez, vecinos del lugar, una heredad de pan llevar y pasto en Zahínos por 15.000 cruzados y una casa. Ante Vasco Yánez, escribano.

Carta de venta. Original. Manuscrito. Castellano. 1 f.r. 27 x 42 cms. Pergamino. Precortesana. R (borde lateral derecho deteriorado por roedores, tinta algo borrosa, algunas manchas de humedad)

Sepan cuantos esta carta vieren como yo Vicente Miguel, hijo de Miguel Arias y yo María Alfonso, su mujer, vecinos de Jerez, cerca Badajoz, conocemos y otorgamos que vendemos a vos Gonzalo Domínguez, escribano, y a vos Teresa Yáñez, su mujer, vecinos de esta dicha villa que estáis presentes, recibientes para vos y para vuestros herederos, una nuestra heredad de llevar pan y pasto que nos habemos en término de aquí de Jerez y en Zahínos. La cual heredad está en tres pedazos que ha por linderos, el un pedazo heredad de Vasco González Gallego todo en derredor y fondo con el Arroyo del Judío, que va el dicho arroyo entre este pedazo de heredad y heredad de Gonzalo Domínguez, yerno de Esteban Fernández y parte con la ribera del Godolín. Y el otro pedazo parte con el dicho Arroyo del Judío y con tierra que Ilaman Carrascosa que es del dicho Vasco González Gallego y enhiesta con heredad del dicho Vasco González. Y el otro pedazo de tierra es el que cupo a nos los dichos vendedores en pareja de la heredad que nos y el dicho Vasco González y su mujer habíamos de consumo. Que ha por linderos este dicho pedazo con el dicho Arroyo del Judío como va a dar el arroyo arriba 
con el poyo grande y de este poyo grande como parte con el alcornocal de Alcobaza y va dar al poyo pequeño y de este poyo pequeño el arroyo ayuso como parte con heredad del dicho Vasco González y va dar el arroyo ayuso con el segundo pedazo que vos vendemos en que están las casas del monte de nos los dichos vendedores y va dar el dicho arroyo del poyo pequeño ayuso con el Arroyo del Judío y con heredad de vos los dichos compradores. Y estos dichos tres pedazos de heredad así deslindados vos vendemos por precio nombrado que de vos recibimos, el cual pasó a nos los dichos vendedores y de vos los dichos compradores, que son quince mil cruzados de esta moneda usual y más una casa que vos los dichos compradores nos dais de más de los dichos quince mil cruzados. La cual casa es aquí en Jerez, que ha por linderos casa de Gonzalo Domínguez, hermano de Francisco Domínguez, y detrás con casa de Vasco Domínguez Zurrón y con dos calles públicas. Y desde hoy día que esta carta es hecha en adelante nos los dichos vendedores nos partimos y desapoderamos de la tenencia y propiedad y señorío que nos habemos en los dichos tres pedazos de heredades que vos vendemos. $Y$ por esta carta apoderamos a vos los dichos compradores en la dicha tenencia y propiedad y señorío y vos damos y otorgamos poder que las entréis por vos mismos y por quien vos quisiereis, sin mandado de alcalde ni de juez ni de otra justicia cualquier, sin pena y sin coto y sin caloña alguna y lo hayáis para vos y para todos vuestros herederos y para quien vos quisiereis, con entradas y con salidas y con todas sus pertenencias y usos y derechos que les pertenecen y pertenecer deben en cualquier manera, así de hecho como de derecho, libres y quitas, desembargadamente para todo siempre jamás. Para vender y dar y donar y trocar y cambiar y enajenar y para hacer de ellas y en ellas todo lo que vos quisiereis así como de lo vuestro mismo que habéis de compra y de justo título. Y obligamos a nos mismos y a todos nuestros bienes que hoy día habemos y habremos de aquí adelante de nos hacer vos sanos los dichos dos pedazos primeros de heredades que vos vendemos a todo tiempo de cualquier embargo que vos sobre ellas hagan, así en juicio como fuera de él y no lo haciendo ni cumpliendo así que vos pechemos los dichos quince mil cruzados del dicho precio con el doblo, con las costas y daños y menoscabos que por esta razón hiciereis y recibiereis, la cual pena tantas vegadas podáis demandar y haber para vos cuantas vegadas nos así por vos fuéramos contra esto que dicho es. Y la pena pagada o no todavía que valga y sea firme esta dicha vendida con todo cuanto en esta carta se contiene. $Y$ sobre todo esto renunciamos y quitamos de nos y de todos nuestros bienes toda ley y todo fuero y todo derecho así eclesiástico como seglar de que nos podamos ayudar. Y quitamos nos de toda excepción y de todas las otras buenas razones y defensiones y excepciones que por nos hayamos o podamos haber que contra esto sea en contrario y otorgamos que nos no valga ni seamos sobre ello oídos en juicio ni fuera de él y señaladamente de la pena. Y por que esto sea firme y valedero para en todo tiempo y no venga en duda nos los dichos vendedores de suso nombrados otorgamos esta carta en presencia de Vasco Yáñez, escribano público aquí en Jerez por nuestro señor el maestre don Fernando Osórez, al cual rogamos y mandamos que la escribiese y la signase con su signo. Hecha la carta en la dicha villa de Jerez, primer día de septiembre, era de mil y cuatrocientos y nueve años. Testigos que a esto fueron presentes para esto llamados, Esteban Fernández, escribano, y Lorenzo Estévez da Maya y Juan Caballero y Fernando Yáñez Bufardo y Juan Domínguez, criado de Juan Yáñez 
Campanón y Martín Fernández Millán y Vicente Guillelme y otros. Y yo Vasco Yáñez, escribano público sobre dicho en la dicha villa de Jerez por el dicho señor maestre, a esto que dicho es presente fui con los dichos testigos y vi en como los dichos Vicente Miguel y María Alfonso, su mujer, recibieron y llevaron en su poder los dichos quince mil cruzados del dicho precio que los dichos Gonzalo Domínguez y Teresa Yáñez le pagaron y esta carta por ruego y otorgamiento de los dichos vendedores escribí e hice aquí mío signo que tal (signum) es y soy testigo (rúbrica).

\section{Estructura documental:}

\section{PROTOCOLO}

1. Intitulación: Vicente Miguel, hijo de Miguel Arias y su esposa María Alfonso, vecinos de Jerez de los Caballeros.

2. Dirección: Gonzalo Domínguez, escribano y su esposa Teresa Yáñez, vecinos del lugar.

\section{CUERPO:}

1. Notificación: Es de tipo general. "Sepan cuantos esta carta vieren".

\section{Dispositivo}

2.1. Acceso al dispositivo: "Conocemos y otorgamos".

2.2. Disposición: "Vendemos".

2.3. Tipo de bien con ubicación y linderos: Una heredad en tres pedazos de pan y pasto en Zahínos.

2.4. Precio: Se expresa en dinero, cruzados y en especie, más una casa con señalamiento de ubicación y linderos.

\section{Cláusulas}

3.1. Cláusula de trasmisión de dominio: "Y desde hoy día que esta carta es hecha en adelante... nos partimos y desapoderamos de la tenencia y propiedad....y por esta carta apoderamos a vos los dichos compradores...".

3.2. Cláusula de libre disposición: "'Damos y otorgamos poder que la entréis por vos mismos... y lo tengáis para vos... para vender y dar, etc...".

3.3. Cláusula de obligación general de personas y bienes: "Y obligamos a nos mismos y a todos nuestros bienes que hoy día habemos y habremos de aquí adelante...".

3.4. Cláusula de saneamiento y defendimiento con sanción: "De nos hacer vos sanos los dichos dos pedazos primeros de heredades que vos vendemos... y no lo haciendo ni cumpliendo así que vos pechemos los dichos quince mil cruzados del dicho precio con el doblo, con las costas y daños, etc". 
3.5. Cláusula renunciativa de derechos: "Y sobre todo esto renunciamos y quitamos de nos y de todos nuestros bienes toda ley y todo fuero y todo derecho, así eclesiástico como seglar, de que nos podamos ayudar".

3.6. Cláusula de corroboración: "Y por que esto sea firme y valedero para en todo tiempo y no venga en duda...otorgamos esta carta...".

\section{ESCATOCOLO}

1. Data: Expresión de lugar, día, mes y año por el sistema de la Era Hispánica.

2. Suscripción de testigos: Se dice que los testigos fueron llamados y a continuación se enumeran.

3. Suscripción del escribano: Con la cláusula de refrendo del nombre del escribano: "Yo Vasco Yáñez" y expresión de su jurisdicción: "Escribano público... por el dicho señor maestre". En la misma el escribano da testimonio público de que la paga de la venta se efectuó en su presencia, supliendo así la falta de dicha cláusula en el cuerpo documental. Le siguen la mención a la "iussio" notarial con el signo escribanil y la rúbrica.

AHN, Clero, carp. 46, no 10

1371, octubre, 12. Jerez

Vasco González Gallego y su esposa Urraca Yáñez, vecinos de Jerez de los Caballeros, venden a Gonzalo Domínguez, escribano, y su esposa Teresa Yáñez, vecinos del lugar, una heredad de pan, pasto y monte en Zahínos por 33.000 cruzados. Ante Vasco Yáñez Cordero, escribano.

Carta de venta. Original. Manuscrito. Castellano. 1 f.r. 28,7 x 22 cms. Pergamino. Precortesana. B (algunas manchas de insectos)

Sepan cuantos esta carta vieren como yo Vasco González Gallego y yo Urraca Yáñez, su mujer, vecinos en Jerez, cerca Badajoz, otorgamos y conocemos que vendemos a vos Gonzalo Domínguez, escribano, y a Teresa Yáñez, vuestra mujer, vecinos de la dicha villa, una heredad de pan y de pasto y de monte nuestra que nos habemos en término de esta villa en Zahínos. La cual heredad ha por linderos heredad de vos los compradores y con la ribera del Godolín y con el alcornocal de Alcobaza. La cual dicha heredad así deslindada vos vendemos por vendida sana y derecha y verdadera, con sus entradas y salidas y pertenencias, cuantas ha de hecho y de derecho debe y le pertenece haber, por precio nombrado que de vos recibimos que son treinta y tres mil cruzados 
de esta moneda que se usa, que son once mil maravedís de esta moneda usual. De los cuales dichos maravedís nos otorgamos por bien entregos y por bien pagados por cuanto pasaron a nuestro poder y sobre esto renunciamos la excepción del derecho de la pecunia no vista ni contada ni recibida. El cual precio sobre dicho otorgamos que es justo y derecho y verdadero. Y desde hoy este día en adelante que esta carta es hecha, nos los dichos vendedores nos partimos y quitamos y desapoderamos de todo el derecho y tenencia y posesión y propiedad y señorío que nos u otro por nos habemos en la dicha heredad. Y por esta carta apoderamos a vos los dicho compradores en la dicha heredad y en la tenencia y posesión y propiedad y señorío para que la entréis por vos mismos y la tengáis por juro de heredad para hacer de ella y en ella todo lo que vos quisiereis así como de cosa vuestra que habéis de compra y de justo título. Y otorgamos y prometemos que ni de la propiedad y tenencia y posesión y señorío de la dicha heredad ni de otro derecho que le pertenezca y pertenecer deba en cualquier manera nos ni otro por nos no movamos pleito ni demanda ni contienda a vos los dichos compradores ni nos hagamos ni pongamos ningún embargo en juicio ni en fuera de él. Y que vos defendamos y amparamos a nuestras propias costas y misiones en juicio y en fuera de él de cualquier o cualesquier persona o personas que vos demanden o quieran demandar la dicha heredad o parte de ella, o vos ponga algún embargo en cualquier manera. Y otorgamos que de la dicha heredad ni de la tenencia y posesión y señorío de ella no habemos hecho vendida ni empeñamiento ni enajenamiento a otra persona ni a otro lugar. Y obligamos nos de vos hacer sana la dicha heredad de cualquier o cualesquier embargo o embargos que vos en la dicha heredad o en parte de ella sea puesto en cualquier manera, en manera que la hayáis vos y vuestros herederos o quien vos quisiereis para hacer de ella y en ella todo lo que quisiereis así como de cosa vuestra que habéis de compra y de justo título. $Y$ otorgamos y prometemos de tener y cumplir y guardar verdaderamente a buena fe, sin mal engaño todas estas cosas y cada una de ellas y de nunca ir ni pasar ni hacer contra ninguna ni alguna de ellas en algún tiempo por ninguna manera. Y si contra ello hagamos o pasamos en cualquier manera que vos rehagamos todo el daño y el menoscabo que sobre ello hiciereis y de más que vos pechemos en pena los dichos maravedís del precio sobre dicho que de vos recibimos con el doblo, con todo el mejoramiento que en la dicha heredad hiciereis y con las costas y misiones que sobre ello recibiereis y la pena pagada o no todavía que tengamos y cumplamos todo cuanto en esta carta se contiene. $Y$ que esta vendida que sea y finque firme y valedera para en todo tiempo y para todo siempre jamás. Y sobre esto expresamente renunciamos la ley del rey en que se contiene que cada compra o vendida que fuere hecha entre partes o por almoneda por menos del derecho precio que se pueda deshacer hasta cuatro años. $Y$ otrosí renunciamos toda ley y todo fuero y todo derecho tanto eclesiástico como seglar y todo uso y toda costumbre y toda otra buena razón y defensión y excepción que por nos y para nos que contra esto sea. Y otorgamos que nos no valga en juicio ni en fuera de él. Y para esto que dicho es tener y cumplir y pagar obligamos a nos y a nuestros bienes que hoy día habemos y habremos de aquí adelante. Y porque esto es verdad nos los dichos vendedores otorgamos esta carta en presencia de Vasco Yáñez Cordero, escribano público aquí en Jerez por nuestro señor el maestre, al cual rogamos y mandamos que vos la de signada con su signo. Hecha en la dicha villa de Jerez, domingo, doce días de octubre, era de 
mil y cuatrocientos y nueve años. Testigos que estaban presentes, Benito Domínguez Zurrón y Ferrand Yáñez Bufardo y Domínguez Estévez da Maya y Juan Delgado y Juan Alfonso, yerno de Juan de Lugo y Juan Rodríguez, criado de Juan Delgado y Álvaro González, hijo de Gonzalo Domínguez y Ferrand Fernández Preciado. Y yo Vasco Yáñez Cordero, escribano público sobre dicho en la dicha villa de Jerez por nuestro señor el maestre, a esto presente fui y esta carta escribí y en testimonio hice este mio sig-(signum)no en testimonio y soy testigo (rúbrica).

\section{Estructura documental:}

\section{PROTOCOLO}

1. Intitulación: Vasco González Gallego y su esposa Urraca Yáñez, vecinos de Jerez de los Caballeros.

2. Dirección: Gonzalo Domínguez, escribano y su esposa Teresa Yáñez, vecinos del lugar.

\section{CUERPO}

1. Notificación: La de tipo general. "Sepan cuantos esta carta vieren".

\section{Dispositivo}

2.1. Acceso al dispositivo: "Otorgamos y conocemos".

\subsection{Disposición: "Vendemos".}

2.3. Tipo de bien con ubicación y linderos: Se trata de una heredad de pan, pasto y monte en Zahínos.

2.4. Precio: Se expresa en la moneda de cruzados y su equivalencia en maravedís.

2.5. Fórmula de aceptación de pago: "De los cuales dichos maravedís nos otorgamos por bien entregos y por bien pagados por cuanto pasaron a nuestro poder".

\section{Cláusulas}

3.1. Cláusula de pertenencia y saneamiento: "Vos vendemos por vendida sana y derecha... con sus entradas y salidas y pertenencias...".

3.2. Cláusula de renuncia a la pecunia non contada: "Renunciamos la excepción del derecho de la pecunia no vista ni contada ni recibida". dero".

3.3. Cláusula del justo precio: "El cual precio... es justo y derecho y verda- 
3.4. Cláusula de trasmisión de dominio: "Nos los dichos vendedores nos partimos y quitamos y desapoderamos de todo el derecho y tenencia y posesión y propiedad, etc... y por esta carta apoderamos, etc".

3.5. Cláusula de libre disposición: "Para que la entréis por vos mismos y la tengáis por juro de heredad para hacer de ella y en ella todo lo que vos quisiereis...".

3.6. Cláusula de defendimiento: "Y que vos defendamos y amparamos a nuestras propias costas y misiones... de cualesquier personas que vos demanden... la dicha heredad...".

3.7. Cláusula de saneamiento: "Y otorgamos que de la dicha heredad... no hemos hecho vendida ni empeñamiento ni enajenamiento, etc... y obligamos nos de vos hacer sana la dicha heredad...".

3.8. Cláusula de libre disposición: "Que la tengáis vos... para hacer de ella y en ella todo lo que quisiereis, así como de cosa vuestra... y de justo título". En esta caso se repite otra vez dicha cláusula, ligada a la anterior de saneamiento, como forma de reforzar la trasmisión de la propiedad.

3.9. Cláusula de obligación de contrato con sanción: "Y otorgamos y prometemos de tener y cumplir y guardar... todas estas cosas... y si contra ello hagamos o pasamos... que vos rehagamos todo el daño y menoscabo... y de más que vos pechemos en pena los dichos maravedís del precio... con el doblo, etc".

3.10. Cláusula de renuncia al justo precio: "Renunciamos la ley del rey... (hace referencia a Alfonso XI y el Ordenamiento de Alcalá de 1348) que cada compra o vendida que fuere hecha entre partes o por almoneda por menos del derecho precio que se pueda deshacer hasta cuatro años".

3.11. Cláusula de renuncia de derechos: "Y otrosí renunciamos toda ley y todo fuero y todo derecho tanto eclesiástico como seglar, etc".

3.12. Cláusula de obligación general de personas y bienes: "Obligamos a nos y a nuestros bienes que hoy día habemos y habremos de aquí adelante".

3.13. Cláusula de corroboración: "Y porque esto es verdad nos los dichos vendedores otorgamos esta carta...".

\section{ESCATOCOLO}

1. Data: Lugar, día completo de la semana, mes y año con la Era Hispánica.

2. Suscripción de testigos: Enumeración sin más de testigos que se dice estar presentes.

3. Suscripción de escribano: Mención del escribano con cláusula de refren- 
do, expresión de jurisdicción, signo escribanil y rúbrica. No se cita la "iussio" notarial.

Diego Yáñez Farfán y su esposa María González, vecinos de Jerez de los Caballeros, venden a Álvaro González Chico y su esposa Catalina Martínez, vecinos del lugar, el quinto que les pertenece de una heredad en Zahínos por 1.200 maravedís. Ante Ferrand Álvarez, escribano.

Carta de venta. Original. Manuscrito. Castellano. 1 f.r. 37 x 30 cms. Pergamino. Precortesana. $\mathrm{R}$ (manchas de humedad y de insectos y tinta muy borrosa)

Sepan cuantos esta carta vieren como yo Diego Yáñez Farfán y yo María González, su mujer, vecinos que somos de la villa de Jerez, cerca Badajoz, otorgamos y conocemos que vendemos a vos Álvaro González Chico y a Catalina Martínez, vuestra mujer, que estáis presentes, vecinos que sois en esta dicha villa, toda la parte y gobierno que nos los sobre dichos habemos y nos pertenece haber de una heredad de vos los dichos compradores que fue de Gonzalo Domínguez, padre de vos el dicho Álvaro González. La cual heredad es en término de esta dicha villa a donde Ilaman Zahínos, que parte y ha por linderos heredad de Zahínos y heredad de Juan Díaz Hidalgo y heredad que fue de Juan Estévez Godino y parte con Alcobaza y con Zamora y con el Godolín. La cual parte y gobierno de la dicha heredad así declarada y deslindada en la manera que dicha es, perteneció haber a nos los sobre dichos por parte de Teresa Martínez, madre de mí la dicha María González, mujer que fue del dicho Gonzalo Domínguez, padre de vos el dicho Álvaro González. La cual parte y gobierno de heredad con la parte y gobierno que a nos pertenece haber de las majadas y ejidos que en la dicha heredad están, vos vendemos por vendida buena, sana y verdadera por precio nombrado que de vos recibimos que son mil y doscientos maravedís de esta moneda que se usa, que dos blancas hacen un maravedí, de los cuales mil y doscientos maravedís nos otorgamos por entregos y pagados por que los recibimos de vos los dichos compradores. Y sobre esto renunciamos la excepción de derecho de la pecunia no vista ni contada ni recibida. El cual precio suso dicho otorgamos nos los dichos vendedores que es justo y derecho y que a tanto vale al tiempo de ahora la dicha parte y gobierno que de la dicha heredad a nos pertenece y no más. Y otorgamos que si alguna cosa más vale, que de la demasía vos hacemos pura y sana donación sin ninguna condición. Y por ende desde hoy día que esta carta es hecha en adelante nos apartamos y quitamos de la tenencia y posesión y propiedad y señorío que a la dicha parte y gobierno de heredad habemos. Y por esta carta apoderamos en ella a vos los dichos compradores y vos damos y otorgamos poder cumplido que la entréis sin 
mandado de alcalde ni de juez ni de otra justicia cualquier y la hayáis para vos y para vuestros herederos y para quien vos quisiereis con entradas y con salidas y con todas sus pertenencias y usos y derechos que le pertenecen y pertenecer deben, libres y quitas desembargadamente para todo siempre jamás. Para vender y dar y donar y trocar y cambiar y enajenar y hacer de ella y en ella todo lo que vos quisiereis y por bien tuviereis, así como de cosa vuestra propia que habéis de compra y de justo y derecho título y de pura y sana donación sin ninguna condición. Y otorgamos de vos hacer sana la dicha parte y gobierno que de la dicha heredad nos pertenece haber a todo tiempo de cualquier embargo o embargos que sobre ella o sobre parte de ella vos salga, así en juicio como fuera de él y no lo haciendo y cumpliendo así, otorgamos que vos pechemos los dichos maravedís que de vos recibimos con el doblo, con todos los mejoramientos que en la dicha parte y gobierno de heredad fueren hechos por pena y en postura asosegada que con vosotros ponemos por cada vegada que nos $u$ otros por nos contra esto que dicho es fuéremos. Y lo así no hiciéremos y la pena pagada o no todavía fincamos obligados y nos obligamos así a buena fe y sin mal engaño de tener y cumplir y haber por firme todo esto que dicho es y en esta carta se contiene. Y para así lo tener y cumplir y pagar la pena si en ella cayéremos, obligamos a nos y a nuestros bienes los que hoy día habemos y habremos de aquí adelante y sobre esto renunciamos y partimos y quitamos de nos toda ley y todo fuero y todo derecho escrito y no escrito y plazo de tercer día y de nueve días y de treinta días y plazo de acuerdo y de consejo y de traslado de esta carta y abogado para ella y toda otra buena razón y defensión y excepción que por nos hayamos o podamos haber, que otorgamos que aunque por nos lo aleguemos que nos no valga en juicio ni fuera de él. Y expresamente renunciamos la ley del derecho en que dice que general renunciación no valga, salvo si aquel que la carta otorgare la renunciare y nos los sobre dichos especialmente así la renunciamos. Otrosí renunciamos la ley del rey en que dice que toda vendida que sea hecha entre partes o en almoneda pública que se pueda deshacer hasta cuatro años. Y por que esto es verdad y sea firme y estable y no venga en duda, nos los dichos Diego Yáñez y María González otorgamos esta carta en presencia de Ferrand Álvarez, notario público en esta dicha villa de Jerez, al cual rogamos que la escribiese o hiciese escribir y la diese a vos los dichos compradores escrita y signada con su signo. Hecha la carta en la dicha villa de Jerez, diez y nueve días del mes de abril, año del Nacimiento de Nuestro Señor Jesucristo de mil y cuatrocientos años. Testigos que estaban presentes para esto Ilamados y rogados, Gonzalo Yáñez Gorjón y Gonzalo Candil y Gonzalo Martín Vallón. Y yo Ferrand Álvarez, notario público sobre dicho de la dicha villa de Jerez a lo que sobre dicho es, que en mi presencia pasó, presente fui y esta carta hice por otorgamiento de los dichos vendedores y escribí e hice aquí este mio sig-(signum)-no en testimonio de verdad y soy testigo (rúbrica). 


\section{Estructura documental}

\section{PROTOCOLO}

1. Intitulación: Diego Yáñez Farfán y su esposa María González, vecinos de Jerez de los Caballeros.

2. Dirección: Álvaro González Chico y su esposa Catalina Martínez, vecinos del lugar.

\section{CUERPO}

1. Notificación: Es de carácter general. "Sepan cuantos esta carta vieren".

\section{Dispositivo}

2.1. Acceso al dispositivo: "Otorgamos y conocemos".

2.2. Disposición: "Vendemos".

2.3. Tipo de bien con ubicación y linderos: La parte y gobierno de una heredad en Zahínos.

2.4. Fórmula de tradición: Se dice que esta heredad fue de Gonzalo Domínguez, padre del comprador, adquirida a través de su esposa Teresa Martínez, madre de la vendedora María González.

2.5. Precio: Se expresa en maravedís y su equivalente en la moneda de blancas.

2.6. Fórmula de aceptación de pago: "Nos otorgamos por entregos y pagados porque los recibimos de vos los dichos compradores".

\section{Cláusulas}

3.1. Cláusula de saneamiento: "Vos vendemos por vendida buena, sana y verdadera.

3.2. Cláusula de renuncia a la pecunia non contada: "Renunciamos la excepción de derecho de la pecunia no vista, etc".

3.3. Cláusula del justo precio: "El cual precio...otorgamos nos los dichos vendedores que es justo y derecho", con mención a la donación de la demasía de precio si la hubiere.

3.4. Cláusula de trasmisión de dominio: "Nos apartamos y quitamos de la tenencia y posesión, etc.... y apoderamos en ella a vos los dichos compradores...".

3.5. Cláusula de libre disposición y pertenencia: "Y vos damos y otorgamos 
poder cumplido que la entréis sin mandado de alcalde ni de juez, etc y la tengáis para vos... con entradas y con salidas y con todas sus pertenencias...para vender y dar, etc".

3.6. Cláusula de saneamiento con defensión y sanción: "Y otorgamos de vos hacer sana la dicha parte...de cualquier embargo... así en juicio como fuera de él y no lo haciendo y cumpliendo así otorgamos que vos pechemos los dichos maravedís... con el doblo, etc".

3.7. Cláusula de obligación general de personas y bienes: "Obligamos a nos y a nuestros bienes, etc".

3.8. Cláusula de renuncia de derechos: "Renunciamos y partimos y quitamos de nos toda ley y todo fuero, etc y plazo de tercer día y de nueve días y de treinta días y plazo de acuerdo y de consejo y de traslado de esta carta y abogado para ella...".

3.9. Cláusula renunciativa específica de derecho: "Expresamente renunciamos la ley del derecho en que dice que general renunciación no valga".

3.10. Cláusula de renuncia al justo precio: "Otrosí renunciamos la ley del rey en que dice que toda vendida...que se pueda deshacer hasta cuatro años".

3.11. Cláusula de corroboración: "Y porque esto es verdad y sea firme y estable y no venga en duda... otorgamos esta carta...".

\section{ESCATOCOLO}

1. Data: Lugar, día, mes y año por el sistema de la Natividad.

2. Suscripción de testigos: Se dice que los testigos estaban presentes porque fueron para ello llamados y rogados.

3. Suscripción de escribano: Cláusula de refrendo con el nombre del escribano: "Yo Ferrand Álvarez", con signo escribanil y rúbrica.

(5)

AHN, Clero, carp. 46, no 8

1400, mayo, 7. Jerez

Luis González Estaso y su esposa Beatriz Vázquez, vecinos de Jerez de los Caballeros, venden a Álvaro González Chico y su esposa Catalina Martínez, vecinos del lugar, el gobierno que les pertenece de una heredad 
con sus casas y majadas en Zahínos por 900 maravedís. Ante Gonzalo Vázquez, escribano.

Carta de venta. Original. Manuscrito. Castellano. 1 f.r. 33,7 x 31,5 cms. Pergamino. Precortesana. B.

Sepan cuantos esta carta vieren como yo Luis González Estaso y yo Beatriz Vázquez, su mujer, vecinos que somos de la villa de Jerez, de nuestras libres y propias voluntades y sin premia alguna, otorgamos y conocemos que vendemos a vos Álvaro González Chico, que estáis presente, y a Catalina Martínez, vuestra mujer, otrosí vecinos de esta dicha villa, toda la parte y gobierno y derecho que nos habemos y nos pertenece de una heredad y casas y majadas que en ella están. La cual dicha heredad es en término de esta villa, que parte toda la dicha heredad con la dehesa de Alcobaza y con la dehesa de Zahínos y con heredad de Juan Díaz y con la ribera del Godolín. La cual parte y gobierno de la dicha heredad que vos así vendemos cupo a mí el dicho Luis González por herencia de Teresa Yáñez, mi madre. La cual dicha parte y gobierno que nos así habemos en la dicha heredad y casas y majadas que con ella están, vos vendemos por vendida buena y sana y verdadera por precio nombrado que son novecientos maravedís de esta moneda usual que ahora corre. De los cuales dichos novecientos maravedís nos damos y otorgamos por bien pagados, por cuanto vos el dicho Álvaro González los disteis y pagasteis a Luis Fernández, hijo de Fernando Fernández, vecino de esta villa, por cuanto se los debía y había de dar yo el dicho Luis González por razón de un caballo de color rucio que yo el dicho Luis González compré del dicho Luis Fernández. El cual caballo es en mi poder y me doy de él por entrego. $Y$ a esto renunciamos la excepción y la ley del derecho de la pecunia no vista ni contada ni recibida. El cual precio sobre dicho otorgamos nos los dichos vendedores que es justo y derecho y que tanto vale al tiempo de ahora la parte y gobierno que nos habemos en la dicha heredad que vos así vendemos y no más. Y si alguna cosa más vale otorgamos que de la demasía vos hacemos pura y sana donación sin condición alguna. Y por ende desde hoy día en adelante que esta carta es hecha nos los dichos vendedores nos partimos y quitamos y desapoderamos de la tenencia y posesión y propiedad y señorío que habemos en la dicha parte y gobierno de heredad que vos comprasteis de nos y por esta carta apoderamos en ella con sus casas y con sus majadas a vos los dichos compradores y vos damos poder cumplido que por vos mismos o por cualquier de vos y sin mandado de alcalde y de juez y de otra justicia cualquier que sea la entréis y la hayáis con sus entradas y salidas y usos y derechos que le pertenecen y pertenecer deben, libres y quitas, desembargadamente para vos y para vuestros herederos. $Y$ para vender $y$ dar $y$ donar $y$ trocar $y$ cambiar $y$ enajenar $y$ hacer de la dicha heredad y en ella todo lo que vos quisiereis y por bien tuviereis, así como de cosa vuestra propia que habéis por la dicha compra y de justo y verdadero título. Y otorgamos de vos hacer sana la dicha parte y gobierno de heredad que vos así vendemos a todo tiempo de cualquier embargo o embargos que vos sobre ella o sobre parte de ella salga o sea puesto, así en juicio como en fuera de él y no vos la haciendo sana o no pudiendo, otorgamos que vos pechemos en pena y postura sosegada que con vosotros ponemos los dichos novecientos maravedís del precio sobre dicho y con el doblo. Y la pena pagada o no pagada todavía fincamos obligados y nos obligamos así a buena fe y sin mal engaño de tener y cumplir 
todo lo contenido en esta carta. Para lo cual tener y cumplir y pagar la pena sin en ella cayésemos obligamos a nos y a nuestros bienes, los que hoy día hemos y habremos de aquí adelante. Y por que estas cosas en esta carta contenidas sean mejor tenidas y guardadas renunciamos y partimos y quitamos de nos toda ley y todo fuero y todo derecho, así eclesiástico como seglar y así en especial como en general y todo privilegio y todo ordenamiento y todo uso y toda costumbre escrito y no escrito y todas otras buenas razones y defensiones y excepciones que por nos hayamos o podamos haber que contra lo otorgado en esta carta o contra parte de ella sea en contrario, que nos no valga ni seamos sobre ello ni sobre parte de ello oídos en juicio ni en fuera de él. Y expresamente la ley del derecho que dice que general renuncia no valga, salvo si el que la carta otorgare la renuncia y nos especialmente así la renunciamos. Y por que esto es verdad y sea firme y valedero ahora y para en siempre jamás otorgamos esta carta en presencia de Gonzalo Vázquez, escribano público de esta dicha villa de Jerez, al cual rogamos y mandamos que la escribiese o hiciese escribir y la signase con su signo. Hecha la carta en la dicha villa de Jerez, siete días del mes de mayo, año del Nacimiento del Nuestro Señor Jesucristo de mil y cuatrocientos años. Testigos que a esto fueron presentes para esto llamados y rogados, Juan Alfonso Sirgado y Juan García, hijo de Alfonso García, labrador y Gonzalo Domínguez, hijo de Gonzalo Domínguez Sisón y Alfonso Sánchez, yerno de Juan Pascual y Gonzalo Martín Candil. Yo Gonzalo Vázquez, escribano público en la dicha villa de Jerez por mi señor el maestre de Santiago, a esto que sobre dicho es que en mi presencia pasó presente fui con los dichos testigos y esta carta hice escribir e hice aquí este mio sig(signum)-no que tal es y soy testigo (rúbrica).

\section{Estructura documental \\ PROTOCOLO}

1. Intitulación: Luis González Estaso y su esposa Beatriz Vázquez, vecinos de Jerez de los Caballeros.

2. Dirección: Álvaro González Chico y su esposa Catalina Martínez, vecinos del lugar.

\section{CUERPO}

1. Notificación: De carácter general. "Sepan cuantos esta carta vieren".

\section{Dispositivo}

2.1. Acceso al dispositivo con espontánea voluntad: "De nuestras libres y propias voluntades y sin premia alguna, otorgamos y conocemos".

\subsection{Disposición: "Vendemos".}

2.3. Tipo de bien con ubicación y linderos: La parte, gobierno y derecho de una heredad con casas y majadas en Zahínos. 
2.4. Fórmula de tradición: Hace referencia a que dicha heredad procede de la herencia por parte de madre del vendedor.

2.5. Precio: Se expresa sólo en maravedís, haciendo mención a la moneda usual en curso en ese momento, pero sin referirse a ella.

2.6. Fórmula de aceptación de pago con manera de pago: "Nos damos y otorgamos por bien pagados, por cuanto...los disteis y pagasteis a Luis Fernández...por cuanto se los debía..." En este caso va implícita la forma en como se produjo la paga del bien vendido, a través de la liquidación de una deuda contraída previamente por el vendedor.

\section{Cláusulas}

3.1. Cláusula de saneamiento: "Vos vendemos por vendida buena y sana y verdadera".

3.2 Cláusula de renuncia a la pecunia non contada: " $Y$ a esto renunciamos la excepción y la ley del derecho de la pecunia no vista ni contada ni recibi$\mathrm{da}^{\prime \prime}$.

3.3. Cláusula del justo precio: "El cual precio...otorgamos...que es justo y derecho y que tanto vale al tiempo de ahora... y no más". Se menciona también la tradicional donación de la demasía de precio, si la hubiere.

3.4. Cláusula de trasmisión de dominio: "Nos los dichos vendedores nos partimos y quitamos y desapoderamos, etc, y por esta carta apoderamos en ella...a vos los dichos compradores...".

3.5. Cláusula de libre disposición con pertenencia: " $Y$ vos damos poder cumplido que por vos mismos...la entréis y la tengáis con sus entradas y salidas y usos y derechos que le pertenecen...para vender y dar, etc".

3.6. Cláusula de defendimiento con sanción: "Y otorgamos de vos hacer sana la dicha parte... de cualquier embargo...así en juicio como fuera de él y no vos la haciendo sana o no pudiendo, otorgamos que vos pechemos en pena...el precio sobre dicho con el doblo".

3.7. Cláusula de obligación general de personas y bienes: "Obligamos a nos y a nuestros bienes, etc".

3.8. Cláusula de renuncia de derechos: "Renunciamos y partimos y quitamos de nos toda ley y todo fuero y todo derecho, así eclesiástico como seglar...que nos no valga ni seamos sobre ello... oídos en juicio ni fuera de él".

3.9. Cláusula renunciativa específica de derecho: "Y expresamente la ley del derecho que dice que general renuncia no valga...".

3.10. Cláusula de corroboración: "Y por que esto es verdad y sea firme y valedero ahora y para en siempre jamás otorgamos esta carta...". 


\section{ESCATOCOLO}

1. Data: Lugar, día, mes y año por el estilo de la Natividad.

2. Suscripción de testigos: Se dice estar presentes y que fueron Ilamados y rogados para ello.

3. Suscripción de escribano: Con cláusula de refrendo: "Yo Gonzalo Vázquez", expresión de jurisdicción con mención al maestre de Santiago, signo escribanil y rúbrica.

\section{Índices}

Insertamos dos índices, toponímico y onomástico de nombres que aparecen en los documentos, más con un posible sentido histórico que diplomático, puesto que no debemos olvidar que el estudio diplomático se inserta a su vez en un análisis del contexto histórico de los documentos. Con todo y sin pretender ser exhaustivos, solamente comentar que una breve ojeada a determinados nombres nos habla en primer lugar de un predominio en el territorio de Jerez de los Caballeros y, por ende, de la baja Extremadura en el siglo XIV, de una población tanto autóctona, de posible origen hispanorromano, como visigodo en nombres y apellidos como: Urraca, versión visigoda de María, o Godino del segundo apellido de uno de los propietarios de heredades en Zahínos. También topónimos como ribera del Godolín. Todo ello normal si pensamos que se trata de una zona ampliamente romanizada, próxima a una importante calzada romana como la Vía de la Plata que venía desde Mérida. Sabemos que precisamente los territorios más romanizados fueron los que luego presentaron un mayor contingente de población visigoda.

En segundo lugar se detecta también una presencia de población norteña, procedente de la colonización del territorio tras la conquista de Extremadura por Alfonso IX de León en el siglo XII. Parece evidente en nombres como el de los escribanos de los tres primeros documentos: Vasco, o el de uno de los vendedores Vasco González Gallego, los testigos Martín Gallego y Juan de Lugo, o Vázquez, todos ellos de clara ascendencia vasca y gallega. Sin olvidar el caso de Alfonso, Gonzalo o Domingo que funcionan bien como nombres o como apellidos, de raigambre castellana.

Todo ello nos está señalando indirectamente la presencia de un sustrato de población, que para el siglo XIV Ilamaríamos mozárabe, de origen o procedencia hispanorromana o visigoda, junto a elementos repobladores que a partir de la conquista cristiana se superponen a ese sustrato, mezclándose con él, pero que aún en el siglo XIV aparecen bastante definidos. Sería deseable profundizar en estas apreciaciones mediante un riguroso estudio onomástico y toponímico del territorio que, apoyado en otras fuentes, nos diese la clave de la estructura social de la baja Extremadura. 


\section{Índice onomástico}

Alfonso García, labrador, padre de Juan García

Alfonso Gorjón, testigo

Alfonso Sánchez, testigo

Alfonso, tendero, vendedor

Álvaro González Chico, hijo de Gonzalo Domínguez, escribano y comprador

Andrés Fernández, señor de Martín Gallego

Bartolomé Xalmillo, propietario

Beatriz Vázquez, esposa de Luis González Estaso

Benito Domínguez Zurrón, testigo

Catalina Martínez, esposa de Álvaro González Chico

Cristóbal Martínez, alfayate, testigo

Diego Yáñez Farfán, vendedor

Domingo Zurame, padre de Luisa Domínguez

Domínguez Estévez da Maya, testigo

Esteban Fernández, escribano, testigo y suegro de Gonzalo Domínguez, propietario

Fernando Fernández, padre de Luis Fernández

Fernando Yáñez Bufardo, testigo

Ferrand Álvarez, escribano

Ferrand Fernández Preciado, testigo

Francisco Domínguez, propietario

Gil Alfonso de la Higuera, hermano de Pedro Alfonso

Gonzalo Candil, testigo

Gonzalo Domínguez, escribano y comprador

Gonzalo Domínguez, propietario

Gonzalo Domínguez, testigo

Gonzalo Domínguez Sisón, padre de Gonzalo Domínguez, testigo

Gonzalo Martín Candil, testigo 
Gonzalo Martín Vallón, testigo

Gonzalo Vázquez, escribano

Gonzalo Yáñez Gorjón, testigo

Juan Alfonso, testigo

Juan Alfonso Sirgado, testigo

Juan Caballero, testigo

Juan de Lugo, suegro de Juan Alfonso

Juan Delgado, testigo y señor de Juan Rodríguez

Juan Díaz, propietario

Juan Díaz Hidalgo, propietario

Juan Domínguez, testigo

Juan Estévez Godino, propietario

Juan García, testigo

Juan Pascual, suegro de Alfonso Sánchez

Juan Rodríguez, testigo

Juan Yáñez Campanón, señor de Juan Domínguez

Lorenzo Estévez da Maya, testigo

Luis Fernández, vendedor de caballo

Luis González Estaso, vendedor

Luisa Domínguez, esposa de Alfonso, tendero

María Alfonso, esposa de Vicente Miguel

María González, esposa de Diego Yáñez Farfán

Martín Fernández Millán, testigo

Martín Gallego, testigo

Miguel Arias, padre de Vicente Miguel

Pedro Alfonso, testigo

Salvador Estévez Veguilla, testigo

Teresa Martínez, madre de María González

Teresa Yáñez, esposa de Gonzalo Domínguez, escribano

Teresa Yáñez, madre de Luis González Estaso 
Urraca Yáñez, esposa de Vasco González Gallego

Vasco Domínguez Zurrón, propietario

Vasco González Gallego, vendedor y propietario

Vasco Yáñez, escribano

Vasco Yáñez Cordero, escribano, hijo de Vasco Yáñez

Vicente Guillelme, testigo

Vicente Miguel, vendedor

\section{Índice toponímico}

Alcobaza, alcornocal y dehesa

Badajoz, ciudad

Espinero, El

Godolín, río

Jerez, cerca Badajoz

Judío, El, arroyo

Lageas, Las

Poyo grande

Poyo pequeño

Tremedal, El

Zahínos, heredad y dehesa

Zamora (dehesa de Zamoreja)

Zorrar de Meas 